NBER WORKING PAPER SERIES

\title{
PREDATION AND ITS RATE OF RETURN: THE SUGAR INDUSTRY, 1887-1914
}

David Genesove

Wallace P. Mullin

Working Paper 6032

\author{
NATIONAL BUREAU OF ECONOMIC RESEARCH \\ 1050 Massachusetts Avenue \\ Cambridge, MA 02138 \\ May 1997
}

Part of this research was undertaken while the first author was a Lady Davis Fellow at the Hebrew University of Jerusalem, and while the second author was John M. Olin Visiting Assistant Professor at the George J. Stigler Center for the Study of the Economy and the State, University of Chicago. We would like to thank Vrinda Kadiyali and participants at numerous workshops for helpful comments. The research assistance of David Burnstein, Sandra Chan and Young Ha is greatly appreciated. This paper is part of NBER's research program in Industrial Organization. Any opinions expressed are those of the authors and not those of the National Bureau of Economic Research.

(C) 1997 by David Genesove and Wallace P. Mullin. All rights reserved. Short sections of text, not to exceed two paragraphs, may be quoted without explicit permission provided that full credit, including (C) notice, is given to the source. 
Predation and Its Rate of Return: The

Sugar Industry, 1887-1914

David Genesove and Wallace P. Mullin

NBER Working Paper No. 6032

May 1997

JEL Nos. L13, L41

Industrial Organization

\begin{abstract}
We study entry into the American sugar refining industry before World War I. We show that the price wars following two major entry episodes were predatory. Our proof is twofold: by direct comparison of price to marginal cost, and by construction of predicted competitive price cost margins that we show to exceed observed margins. We argue that predation occurred only when the relative cost of it to the dominant firm was small, and that it was most probably used to deter future capacity additions. It was also used to lower the purchase price of preexisting firms after one entry episode.
\end{abstract}

David Genesove

Department of Economics

E52-380A

Massachusetts Institute of Technology

Cambridge, MA 02139

and NBER

genesove@athena.mit.edu
Wallace P. Mullin

Department of Economics

Michigan State University

East Lansing, MI 48824-1038

and NBER

wpmullin@msu.edu 


\section{Introduction}

The continued exercise of market power depends upon deterring entry. Recent theoretical work has clarified the range of strategies available to an incumbent firm, giving support to the potential rationality of predatory strategies. Because entry is a dynamic process, and an incumbent's actions to shape its competitive environment necessarily involve dynamic concerns, the issue is best explored by tracing the evolution of a single industry over a long duration.

This paper studies entry into the American sugar refining industry in the decades following the formation of the Sugar Trust. Initially organized in 1887, the Sugar Trust was reorganized as the American Sugar Refining Company (ASRC) in 1891, and by 1909 the company was the ninth largest corporation in the United States. In 1910, the federal government filed an antitrust suit against ASRC as part of the same political movement which brought prosecutions against Standard Oil, American Tobacco, and U.S. Steel. Surprisingly, the evolution of the sugar consolidation has received far less scrutiny from economists than that accorded these other consolidations.

Two entrants, Claus Spreckels and Arbuckle Brothers, were met with sharp decreases in price. These price wars lasted about two years, albeit with some interruptions, and included extended periods in which the price-cost margin fell to zero, or below. We interpret these price wars as predation by ASRC. Our evidence is in part based upon a direct comparison of price to marginal cost. As we have argued in other work (Genesove and Mullin, 1995), the simple production technology of sugar refining and contemporary audits and testimony combine to provide a direct and highly credible measure of marginal cost.

Because estimates of marginal cost are always controversial, we present a second line of evidence, which relies upon the pattern of capacity constraints in the industry and models of competition. Using demand estimates and firm capacity figures, we construct predicted competitive price cost margins and show that they exceed observed margins. This conclusion is robust to our measure of marginal cost as it holds even when the non-raw sugar component of marginal cost is assumed to be zero.

An allegation of predatory conduct is always controversial, whether levelled in the courtroom or the classroom. Our claims concerning ASRC's behavior therefore engage us in two debates, one particular to the sugar refining industry and the 
other, a more general debate about the empirical relevance of predatory acts.

Research on this period of the industry contains no dispute about the fact of the price wars. Both Zerbe (1969) and Eichner (1969) agree that entry triggered sharp reductions in refined prices. They differ in the interpretation. Their arguments, while closely tailored to the particular facts of the sugar industry, evoke the more general debate about whether predation can be a rational strategy, and whether it occurs.

There are two explanations for each price war. First, the mere fact of entry may have led to increased competition and hence lower prices. Likewise, in this view, the end of the price war reflected no more than the increased concentration engendered by merger agreements. This is Zerbe's position, although only fully articulated with respect to the Arbuckle Brothers war. A second interpretation is that the price wars were predatory. This interpretation is really an umbrella for several different explanations, each corresponding to a model of rational predation. (See Milgrom and Roberts (1982), Kreps and Wilson (1982), Bolton and Scharfstein (1990) and Cabral and Riordan (1994) for signalling, reputation, long purse and learning curve rationales for predation.) Eichner (p. 227) is in this vein in arguing that the price wars "demonstrated that any group invading the sugar refining industry would have to be prepared to face substantial losses. This in itself had a certain deterrent value and reinforced the barriers already in existence." Thus he ascribes a reputation motive to ASRC.

We consider each explanation in our analysis of the major entry episodes, bringing both strategic thinking and market data to bear.

A note about our definition of the term predation. Although this paper is not explicitly about antitrust, predation is a buzzword that automatically brings to mind a vast legal literature and caselaw. So there is a need to distinguish between a legal or normative standard and a scientific or positive one. Practical difficulties in implementing a legal standard may deter one from classifying as predatory in a legal sense what one is prepared to thus classify in a positive sense.

We could, and perhaps, will, argue about the appropriate positive standard. But at a minimum, under any positive standard, any evidence for predation must exclude competitive conduct as an explanation. By competitive conduct, we mean the static noncooperative equilibrium outcome in either prices or quantities, as we outline in section 3.3 on models of competition, and in the Appendix.

Our broad definition of predation is any action an incumbent firm undertakes that sacrifices its own current profits in order to reduce its rival's profits and thereby either constrain entry or induce exit. This strategic effect could operate 
by altering the rival's cash flows, its perceptions of market conditions, or its beliefs about the incumbent's likely future actions. ${ }^{1}$

We operationalize this concept by constructing as the price of predation to ASRC the ratio of its losses in the predatory war to the entrant's losses. We are thus conceiving of ASRC as "purchasing" losses for its rival by paying a price in foregone current profits. The usefulness of this measure is demonstrated in the two entry episodes, both of which are marked by respites in the price war in the summer, the high season of sugar demand. We demonstrate that predation was relatively more costly to ASRC in high than in low season, and so the respite reveals the limits to ASRC's willingness to pay for predation.

The plan of this paper is as follows. The next section provides an overview of the industry's history. In section 3 we outline the competitive environment in which ASRC operated. This includes a discussion of the cost structure of sugar refining, the difficulty of entry, and an outline of possible modes of pricing behavior under these conditions. The next three sections address two entry episodes that sparked fierce price wars. Section 4 examines the Arbuckle Brothers entry and price war in detail, while section 5 examines the Spreckels Senior episode. Section 6 calculates internal rates of return for various theories of predation. Section 7, which concludes, briefly comments on other entrants. These were initially accommodated, but eventually bought out by ASRC. Accommodation seems to have depended upon the absence of a cross-market motive for entry, and the entrant's capacity.

\section{Historical Overview}

The history of the American sugar industry is admirably chronicled by Eichner (1969) and Zerbe (1969). Both authors provide invaluable guidance for understanding the industry, and should be consulted for a more detailed chronology than that presented here. For a contemporary chronicle of the sugar industry, nothing compares with Willett and Gray's Weekly Statistical Sugar Trade Journal. That trade publication is the source for most of our data and much of our supporting information concerning the industry.

\footnotetext{
${ }^{1}$ This definition is in accordance with at least one suggested legal standard. "Predatory pricing behavior involves a reduction in price in the short run so as to drive competing firms out of the market or to discourage entry of new firms in an effort to gain larger profits via higher prices in the long run than would have been earned if the price reduction had not occurred." (Joskow and Klevorick, pp. 219-220.)
} 
After several unsuccessful attempts at collusion, the Sugar Trust was formed in December 1887 as a consolidation of 18 firms controlling $80 \%$ of the industry's capacity. The 20 plants owned by the original Trust members were quickly reorganized and reduced to ten. Refined prices rose $16 \%$, and entry soon followed. ${ }^{2}$

The first entrant was Claus Spreckels Senior who, in December 1889, completed a plant in Philadelphia. ${ }^{3}$ That led first to a two-year price war, and then to ASRC, the successor to the Trust, acquiring the Spreckel's Philadelphia plant along with those of firms that had remained outside the original Trust. ${ }^{4}$ These acquisitions were completed by April 1892 and ASRC's capacity share rose to $95 \%$.

This earliest episode exemplified one pattern for the subsequent history of the sugar industry: high levels of concentration, punctuated by episodes of entry that engendered price wars and later acquisition by or accommodation with ASRC.

But not all entrants fit this pattern. In the next several years, the degree of concentration slowly declined, as a series of firms entered, each at a relatively small-scale. ${ }^{5}$ Five firms entered in all, each with a single plant, with an average capacity of 1340 barrels of refined sugar per day. This was in contrast to the 49,500 barrels capacity of ASRC and associated "friendly" companies. ${ }^{6}$ By 1896 , contemporary publications indicate that an understanding had evolved between ASRC and the new, so-called independents.

The next phase of the industry's competition began in 1898, with the entry of the Arbuckle Brothers, a large wholesale grocer firm and the dominant roaster of coffee in the United States. Its position in coffee was due to a patent on a packaging machine, which enabled it to sell coffee in small packages, rather than in bulk form. From 1892-1896, it applied the same technology to sugar, buying refined sugar from ASRC and then reselling packaged sugar. In September 1896 Arbuckle Brothers announced its intention to enter sugar refining. ASRC entered coffee roasting a few months later by purchasing another firm, and a coffee price war ensued. Construction of the Arbuckle Sugar Refining plant took almost two years, finally producing in August 1898.

\footnotetext{
${ }^{2}$ The average refined price rose from $\$ 6.013$ (per hundred pounds) in 1887 to $\$ 7.007$ in 1888 . From Willett and Gray, cited by Eichner, p. 343.

${ }^{3}$ Spreckels refined sugar on the West Coast, while the Sugar Trust was centered on the more populous East Coast. The Sugar Trust acquired a plant in California in spring 1888, touching off a price war on the West Coast. Spreckel's entry into Philadelphia can therefore be viewed as retaliation.

${ }^{4}$ The Sugar Trust was reorganized as a corporation in 1891.

${ }^{5}$ Vogt, p. 49 lists the individual refineries, with their capacities and their date of entry.

${ }^{6}$ Vogt, p. 48.
} 
Another entrant, the Doscher refinery, began production in November of that year. When fully operational, each of these new plants had a capacity of 3,000 barrels daily. This precipitated a severe price war, marked by pricing at or below cost, shutdown by the independent refiners, and the partial shutdown of Doscher. With the exception of one "respite" in the price war, the war continued until May 1900 , when the Doscher refinery merged with two of the major independents to form the National Sugar Refining Company, in a transaction organized by the ASRC President. Arbuckle Brothers remained in the industry.

The next several years witnessed both successful and unsuccessful attempts at entry. Claus Spreckels Jr., the son of the senior, founded the Federal Sugar Refinery in Yonkers, New York in 1901, and managed to achieve a toehold in the industry by 1902-1904. Adolph Segal, who in 1895 had constructed a refinery in Camden, New Jersey and then sold it to ASRC before it ever went into production, began construction of a second plant in Philadelphia 1901. Two years later, with the plant nearly complete, Segal's bankruptcy pushed the refinery into receivership. Production at the plant began only in 1912, after the refinery was sold to bondholders and refurbished. ${ }^{7}$

ASRC's attempts to acquire and maintain dominance did not escape antitrust scrutiny. In 1910 the Federal government filed suit, charging monopolization and restraint of trade, seeking the dissolution of ASRC. Although this case was not formally resolved until a consent decree was signed in 1922, the government's victories in the American Tobacco and Standard Oil cases in 1911 led ASRC to initiate partial, "voluntary," dissolution. ${ }^{8}$

The industry's evolution is captured by Table 2.1, which reports the market share of ASRC, or its predecessor, the Sugar Trust, from 1887-1914. ASRC's market share was always below its share of industry capacity.

\section{The Competitive Environment}

\subsection{Technology of Sugar Production}

Refined sugar was a homogenous product. It was shipped to grocers in barrels, who in turn packaged the sugar for final consumers without any identification of

\footnotetext{
${ }^{7}$ Willett and Gray, November 1, 1906; December 6, 1906; November 29, 1911; March 18, 1912; August 22, 1912.

${ }^{8}$ There were also earlier antitrust actions. In 1892 the government challenged American Sugar's acquisition of several Philadelphia refineries in the E.C. Knight Case. The Supreme Court's decision in 1895 upheld the acquisition.
} 
Table 2.1: Evolution of Industry Capacity

\begin{tabular}{|c|c|c|c|c|c|c|}
\hline \multirow[b]{2}{*}{ Year } & \multirow{2}{*}{$\begin{array}{l}\text { American Sugar } \\
\text { Refining Co.'s } \\
\text { Market Share }\end{array}$} & \multicolumn{3}{|c|}{$\begin{array}{c}\text { Capacity: } \\
\text { (millions of lbs per day) }\end{array}$} & \multicolumn{2}{|c|}{$\begin{array}{c}\text { ASRC's } \\
\text { Capacity Share }\end{array}$} \\
\hline & & ASRC & National S.R. Co. $\dagger$ & Other & Unadjusted & Adjusted \\
\hline 1887 & 79.0 & & & & & \\
\hline 1888 & 75.0 & & & & & \\
\hline 1889 & 66.0 & & & & & \\
\hline 1890 & 67.7 & 11.56 & 0 & 3.57 & 76.4 & 76.4 \\
\hline 1891 & 65.2 & 11.56 & 0 & 4.28 & 73.0 & 73.0 \\
\hline 1892 & 91.0 & 11.56 & 0 & 4.08 & 74.0 & 74.0 \\
\hline 1893 & 85.7 & 15.47 & 0 & 0.77 & 95.3 & 95.3 \\
\hline 1894 & 77.0 & 15.47 & 0 & 1.79 & 89.7 & 89.7 \\
\hline 1895 & 76.6 & 15.47 & 0 & 2.21 & 87.5 & 87.5 \\
\hline 1896 & 77.0 & 15.47 & 0 & 2.21 & 87.5 & 87.5 \\
\hline 1897 & 71.4 & 16.15 & 0 & 2.31 & 87.5 & 87.5 \\
\hline 1898 & 69.7 & 16.15 & 0 & 2.31 & 87.5 & 87.5 \\
\hline 1899 & 70.3 & 16.15 & 0 & 3.57 & 81.9 & 81.9 \\
\hline 1900 & 70.1 & 16.15 & 0 & 4.79 & 77.1 & 77.1 \\
\hline 1901 & 62.0 & 16.15 & 3.26 & 2.55 & 73.5 & 88.4 \\
\hline 1902 & 60.9 & 16.15 & 3.26 & 2.55 & 73.5 & 88.4 \\
\hline 1903 & 61.5 & 16.15 & 3.40 & 3.26 & 70.8 & 85.7 \\
\hline 1904 & 62.3 & 16.15 & 3.40 & 3.26 & 70.8 & 85.7 \\
\hline 1905 & 58.1 & 16.15 & 3.40 & 3.64 & 69.6 & 84.3 \\
\hline 1906 & 57.3 & 16.15 & 3.40 & 4.32 & 67.7 & 81.9 \\
\hline 1907 & 56.8 & 16.15 & 3.40 & 4.49 & 67.2 & 81.3 \\
\hline 1908 & 54.3 & 16.15 & 3.40 & 4.49 & 67.2 & 81.3 \\
\hline 1909 & 50.4 & 16.15 & 3.40 & 4.83 & 66.2 & 80.2 \\
\hline 1910 & 49.2 & 16.15 & 3.40 & 4.83 & 66.2 & 80.2 \\
\hline 1911 & 50.1 & 16.15 & 3.40 & 6.70 & 61.5 & 61.5 \\
\hline 1912 & 45.5 & 16.15 & 3.40 & 6.70 & 61.5 & 61.5 \\
\hline 1913 & 44.0 & 16.15 & 3.40 & 7.04 & 60.7 & 60.7 \\
\hline 1914 & 43.0 & 16.15 & 3.40 & 7.55 & 59.6 & 59.6 \\
\hline
\end{tabular}

The market share figures are from Willett and Gray. The capacity figures are from Willett and Gray, as supplemented by testimony before the Industrial Commission or the Hardwick Committee.

†The National Sugar Refining Company of New Jersey was formed at the end of the Arbuckle War in 1900. Because a controlling interest of its stock was owned by ASRC and ASRC's President, the National was run in harmony with ASRC from its inception until this control was relinquished in 1911-1914. ASRC's Adjusted Capacity Share counts the National's capacity as part of ASRC for 1901-1910 inclusive. 
the manufacturer. ${ }^{9}$ Prices therefore tended toward uniformity.

The production technology of sugar is simple to describe. Raw sugar is transformed at a fixed coefficient into the final product, which is refined sugar. In this period, most refined sugar in the United States was derived from sugar cane. Sugar cane was initially processed into raw sugar, a form which can be transported and stored for later refining. The standard grade of raw sugar, whose homogeneity was ensured by polariscope testing, was $96 \%$ pure sugar, or sucrose, and $4 \%$ water and impurities. In fact, there was some loss of sugar in the refining process, so 100 pounds of raw sugar would yield only 92.5 to 93 pounds of refined sugar. ${ }^{10}$ This technological coefficient remained unchanged over our sample period and beyond. ${ }^{11}$ Most of the raw sugar refined in the U.S. was produced in the tropics, especially Cuba, although Louisiana was an important domestic source. The raw sugar was then "melted," purified, and crystallized by refiners into refined sugar, which is $100 \%$ sucrose.

The cane refiners utilized a common technology. ${ }^{12}$ Marginal cost was constant up to plant capacity, and infinite beyond that. These plant capacities were known both to industry participants and observers. In addition to the materials cost of raw sugar, variable costs also included labor and other costs. The constant marginal cost of sugar refining, $c$, can therefore be summarized by:

$$
c=c_{o}+1.075 * P_{R A W}
$$

where $c$ represents the marginal cost of producing 100 pounds of refined sugar, $c_{o}$ represents all variable costs other than the cost of raw sugar itself, and 1.075 is the coefficient of the fixed-coefficient production technology between raw sugar and refined sugar.

Inferring the value of $c_{o}$ is less straightforward. Nevertheless, we have a number of different sources of evidence that are consistent with each other. Our best

\footnotetext{
${ }^{9}$ James Jarvie, partner in Arbuckle Brothers, June 15, 1899 testimony, Report of the U.S. Industrial Commission, (hereafter, IC) Volume I, Part 2, 1900, p. 146-147. Arbuckle Brothers introduced the practice of selling refined sugar to grocers in labelled $2 \mathrm{lb}$. and $5 \mathrm{lb}$. packages. Yet even they sold most of their sugar in barrels.

${ }^{10}$ Testimony of Stephen Buynitsky, an official from the Customs division of the Treasury Department, June 10, 1899, IC, Volume I, Part 2, 1900, p. 44.

${ }^{11}$ See U.S. Tariff Commission, Refined Sugar: Costs, Prices and Profits, Washington 1920. The evidence there is drawn from government audits of the refiners' books

${ }^{12}$ Henry Havemeyer of ASRC and Claus Doscher both testified that the general processes of sugar refining were common to all refiners. June, 1899 testimony, IC, Volume I, Part 2, 1900, p. 100, p. 112 .
} 
estimate of $c_{o}$ is 26 cents (per hundred pounds) in constant 1898 dollars, but we admit a range of estimates from $16 \phi$ to $26 \phi$.

The earliest evidence on $c_{o}$ comes from testimony before the Industrial Commission in 1899 , which was coincident with the Arbuckle Brothers price war. ${ }^{\mathbf{1 3}}$ Henry Havemeyer, President of ASRC, testified that at a margin of less than $50 \propto$ a hundred pounds "the refineries are running at a loss". ${ }^{14}$ By "the margin", Havemeyer meant the difference between the price of 100 pounds of refined sugar and 100 pounds of raw sugar. Because raw sugar was transformed into refined sugar at less than a one-for-one basis, this "margin" does not represent a true net-of-raw-sugar-costs margin. One needs to know the price of raw to infer that value, which is $P-1.075 \times P_{R A W}$ and which we denote the "proper margin." A partner in Arbuckle Brothers conveniently provides that price for us: ${ }^{15}$ "[the cost of refining is] from 50 to 60 points, or one-half to six-tenths of a cent per pound. In other words, if raw sugar costs $4 \frac{1}{2}$ cents a pound, it will cost over 5 cents up to $5 \frac{10}{100}$." Subtracting $4 \frac{1}{2} \times 1.075$ from a total cost of 5 or $5 \frac{10}{100}$, we obtain a value of $c_{o}$ ranging between $16 \phi$ and $26 \phi$.

Yet another witness provided a detailed breakdown on the components of $c_{o}$ : $5 \notin$ for brokerage and government tax, $10 \notin$ for packages, $20 \phi$ for wages, fuel, boneblack, repairs and sundries, less $10 \phi$ for the value of by-products, principally syrup, for a total of $25 \% .^{16}$

At the Hardwick Committee hearings of 1911, the cost of refining was solicited of the refining companies once again. Various people quoted a cost between $60 \phi$ and $65 \%$ per 100 pounds, at a time at which raw was selling for $\$ 4.00$ per 100 pounds. This implies a value of $c_{o}$ ranging between $30 \phi$ and $35 \phi$ in nominal terms, or $22 \phi$ and $26 \phi$ in constant 1898 dollars. $^{17}$

In addition to the testimony from these two hearings, audits conducted by the U.S. Tariff Commission between 1914 and 1919 are also available. ${ }^{18}$ Corrected for accounting depreciation (which is not included in the previous estimates) and the value of the syrup, the estimated value of $c_{o}$ for 1914, the last year in our sample,

\footnotetext{
${ }^{13}$ The testimony on costs is summarized in Volume I, part 1, pp. 65-66.

${ }^{14}$ Henry Havemeyer, June 14, 1899 testimony, $I C$, Volume I, Part 2, 1900, p. 112.

${ }^{15}$ James N. Jarvie, June 15, 1899 testimony, IC, Volume I, Part 2, 1900, pp. 138-139.

${ }^{16}$ The $10 \&$ for packages is confirmed by a Bureau of Labor Statistics audit in 1913, that showed it to vary between $9.4 \phi$ and $10.8 \phi$, with an average of $10.2 \phi$, (in 1898 dollars), at selected months in 1905, 1910 and 1911. Bureau of Labor Statistics, 1913.

${ }^{17}$ Constant dollar prices are computed from the wholesale price index in Hanes (1993).

${ }^{18}$ U.S. Tariff Commission, 1920, p. 33.
} 
is $35 \phi$ in nominal terms, or $25 \phi$ in 1898 dollars. $^{19}$

It might be objected that some part of these estimates of $c_{o}$ constitute fixed cost. Refinery inputs included, aside from raw sugar, containers, fuel, boneblack and labor. Only the last of these is a serious candidate for a fixed cost. Among our sources, only the U.S. Tariff Commission reports labor costs separately, ascribing a cost of $7.24 \not$ to labor. So, even were all labor fixed, this would reduce that source's estimate of $c_{o}$ to $18 \phi$, still within our range. If we then subtract the Commission's figure of $1.7 \notin$ for repairs and sundries, we reach our lower estimate of $16 \%$. Of course, some part of labor must have been variable. The 1909 Census of Manufactures, the first to report cane sugar refining separately from other parts of the sugar cane industry, reports that payments to salaried workers constituted 23 percent of total labor payments. ${ }^{20}$ If we take that proportion as the part of labor costs that was fixed, though, of course, not sunk, then the estimate of $c_{o}$ would $24 \phi^{21}$

We therefore take $26 \notin$ as our best estimate of $c_{o}$, since that value is supported by the most and best evidence. At times, however, we will also make use of $16 \phi$ as a lower estimate. This range reflects our ignorance, not differences in refining costs among firms. There was general agreement among the witnesses at the Industrial Commission hearings that refiners shared the same technology, and a commission merchant for one of the independents testified that "it is possible that the [larger houses] can refine at a smaller margin than the others. ... [but] it can [not] amount to a great deal; I suppose 3 to 5 cents a hundred would represent the difference." 22

\footnotetext{
${ }^{19}$ To make the figures compatible to the quoted estimates, we subtracted the reported values of $1.3 \notin$ for depreciation and $5.6 \phi$ for receipts for by-products from the reported total refinery cost of $42.0 \%$, to arrive at an estimate of 35.1ф. The 1915 and 1916 figures are similar. From 1917 on, the figures increase, presumably reflecting changing relative prices consequent of the war, as well as the regulation of the sugar industry in those later years.

${ }^{20}$ The figure is for all of the United States. However, the 1929 Census, shows that this proportion does not differ very much across the regions.

${ }^{21}$ Labor fixity may arise also from hoarding specialized, non-salaried labor over the seasonal cycle. Indeed, as will be seen, the predatory periods occured during the low season of winter and early spring. However, ASRC's production during these periods must have been unusually large - both because price was abnormally low and because the small fringe firms were shut down much of the time (see Section 4.1). Indeed, industry production during the first half of 1899 exceeded all but two of the previous half-years since 1890 .

${ }^{22}$ James Post, $I C$, Volume I, Part 2, 1900, p. 151. Also, see footnote 55.
} 


\subsection{The difficulty of entry}

Although the near uniformity of production costs suggests a common, known technology, entrants were drawn from a limited pool. As Eichner points out, they were typically either owners of refineries who had sold out in the 1887 consolidation, or their brothers or sons. Paradoxically, the very consolidation of the industry, and its consequent rationalization of physical assets, created a pool of potential entrants. The exceptions to the rule are Arbuckle Brothers and Segal. Arbuckle Brothers had the patented packaging machine to compensate for its unfamiliarity with the sugar industry. Moreover, it was able to develop or acquire the requisite expertise. It developed expertise in sugar merchandizing in the mid-1890s, while buying refined sugar from ASRC, repackaging it with its machine, and selling small packages of sugar. It acquired production expertise in sugar production by hiring the superintendent of ARSC's Boston plant. ${ }^{23}$ As for Segal, he never really proved he was capable of constructing a workable sugar refinery. ${ }^{24}$

In 1900 , the estimated cost of a refinery with a capacity of 3,000 barrels per day ranged from $\$ 1,500,000$ to $\$ 2,500,000 .{ }^{25}$ Much of this cost was sunk. The plant and machinery were almost entirely specific to the sugar industry. ${ }^{26}$ The land, which, in order to unload imported raw sugar directly into the plant or nearby warehouses, was on the waterfront and so a significant part of the refinery's cost, was also developed in a specialized manner. ${ }^{27}$ Indeed, our research of the sugar industry from 1887 through the 1930s has uncovered only a single conversion of a sugar cane refinery into some other manufacturing purpose. ${ }^{28}$ This is especially noteworthy given that ASRC retained reserve capacity throughout these years, including the price war periods.

To these entry costs one must add the estimated $\$ 2,000,000$ in working cap-

\footnotetext{
${ }^{23}$ Willett and Gray, January 21, 1897, and Fugate, p. 60 .

${ }^{24}$ See Section 7.

${ }^{25} I C$, Volume I, Part 1, 1900, p. 67.

${ }^{26}$ Philip G. Wright, Sugar in Relation to the Tariff, 1924, p. 29. Refiner Claus Doscher testified that "If anything turns up that makes your plant useless for sugar refining, you have got nothing left that is worth anything for anything else." $I C$, Volume I, Part 2, 1900, p. 97.

${ }^{27}$ One witness estimated the replacement cost of two particular refineries at $\$ 1,700,000$ each The land was valued at $\$ 600,000$ for a waterfront location in Brooklyn, and $\$ 250,000$ for a location in Yonkers. IC, Volume I, Part 2, 1900, p. 152.

${ }^{28}$ This was Segal's Camden, New Jersey plant, which ASRC purchased in 1896 . The plant was never operated as a sugar refinery. Its machinery was transferred to other ASRC plants, then used as a storehouse until it was sold to a manufacturer of cereal foods in 1905 . Willett and Gray, March 2, 1905.
} 
ital, which would have been needed for the stock of raw sugar and for credit to brokers. ${ }^{29}$ None of this, of course, was sunk.

Entry was far from instant. Building a refinery took from a year to a year and a half, as a several-story refinery was constructed, along with adjacent warehouses and docks. ${ }^{30}$ Production would start at a low level, as machinery was tested and fixed. It might take a month or more for production to reach capacity. There was also substantial uncertainty over when production would start. ${ }^{31}$

\subsection{Models of Competition and Collusion}

Here we review a number of basic models of competition and collusion, specialized to the technological conditions that prevailed in the sugar refining industry. The combination of identical constant marginal cost $(c)$ until capacity, a capacity that exceeds demand at marginal cost for one firm and small capacities for the rest $(K)$, turns out to be convenient, for it implies that many of the modes of conduct typically assumed in theoretical models have very similar, if not identical, outcomes. A more detailed discussion of collusive equilibria is presented in the Appendix.

The dominant firm and competitive fringe model assumes price taking by all firms other than one large firm, here ASRC. Because marginal cost is constant until capacity, there is no price responsiveness by the fringe for prices exceeding marginal costs; whatever price above $c$ that ASRC sets, the fringe will always produce to capacity. In this model, the equilibrium price $\left(p^{d}\right)$ is that which maximizes profits according to ASRC's residual demand, $D(p)-K$, which is the difference between market demand and fringe capacity. The fringe profits are $\left(p^{d}-c\right) K$.

Other static models of competition yield similar results. The Cournot equilibrium is identical to the dominant firm equilibrium, so long as the fringe's capacity is sufficiently small (i.e., less than the per-firm Cournot equilibrium output in the absence of capacity constraints). The outcome of the Bertrand-Edgeworth model, which has an equilibrium only in mixed strategies, is somewhat different, but it,

\footnotetext{
${ }^{29}$ James Post, IC, Volume I, Part 2, 1900, p. 152.

${ }^{30}$ Willett and Gray's description of the Doscher refinery in 1898 highlights the chief features: "The buildings are completed, including the boiler house, filter house, main refinery and packing department, side by side in the order named, or practically one immense building, eleven stories in heighth and about 300 feet in length. On the opposite side of the street is another large building in which are the offices and machine shops. It has abundunt wharf room and sheds covering $150 \times 400$ feet for storing raw sugars." Willett and Gray, September 22, 1898, p. 5 .

${ }^{31}$ Willett and Gray, June 2, June 23, July 7, August 181898.
} 
too, shares many features common to the dominant firm model. The upper bound of the support of the Bertrand equilibrium prices is equal to $p^{d}$, the lower bound, $p,{ }^{32}$ exceeds marginal cost, and ASRC's expected profits are the same as its deterministic Cournot profits. The fringe's profits are $(\underline{p}-c) K$, and so lower than in the dominant firm model, but the property that they are proportional to the fringe's capacity and linear in its costs is maintained.

Collusion can be modelled by means of repeated games. The asymmetry of capacity brings to the fore an indeterminacy in the equilibrium solution for repeated games that is often ignored: there is a range of market shares that are sustainable, even for a given total industry output. ${ }^{33}$ Only by appending a bargaining model can a unique outcome be obtained.

There is a simple test to determine whether conduct is collusive. A collusive equilibrium is sustainable only if the fringe produces at less than its capacity. Otherwise, ASRC's collusive profits would be, at most, its dominant firm profits (by definition of the same) - which is what ASRC would earn in a competitive reversion. Thus it could not be punished for deviating from such a configuration. That logic fails, however, when firms collude not just on price or output, but on the level of capacity itself. In that scenario, price would exceed the competitive level, ASRC would accept profits lower than dominant firm profits, and a fringe firm that expanded its capacity would be credibly punished by ASRC lowering the price to the competitive level.

The results of this section are robust to small differences in costs between firms. Hold the dominant firm's costs at $c$, and denote the fringe's cost as $c_{f}$. Then so long as $c_{f}<\underline{p}$, the dominant firm-Cournot equilibrium is unchanged, as is the support of equilibrium prices of the Bertrand model. The dominant firm's profits are unchanged in all static models, while the fringe's profits fall by $\left(c_{f}-c\right) K$. All the properties of equilibria of repeated games noted above continue to hold.

${ }^{32}$ The lower bound is the price at which industry profits equal the dominant firm's profits:

$$
(\underline{p}-c) D(\underline{p})=\left(p^{d}-c\right)\left(D\left(p^{d}\right)-K\right)
$$

${ }^{33}$ For example, in the repeated Bertrand game with no capacity constraints, any configuration in which the market share of the larger firm is less than the discount factor is sustainable. 


\section{Arbuckle Brothers}

We examine this entry episode first because we know the most about it. It coincided with Congressional hearings into the sugar refining industry, and received extensive coverage in Willett and Gray.

The sequence of events which led Arbuckle Brothers to construct its own sugar refining plant is unclear. Arbuckle Brothers owned a patented packaging machine which it used in the mid 1890 s to package and resell sugar they purchased from ASRC. There is conflicting testimony on the sequence of the following three events, but no dispute about their occurrence. One, ASRC offered to buy the packaging machine, but Arbuckle Brothers refused to sell it. Two, Arbuckle Brothers asked for a discount on the refined sugar they were purchasing from ASRC (Arbuckle Brothers was paying the same rate as any other customer), but ASRC refused. Three, Arbuckle Brothers announced its intention to begin manufacturing sugar.

Figure 1 shows the path of refined and raw prices from the start of 1897 through the close of 1900 , at weekly frequency. There is a sharp reduction in refined prices between the Arbuckle Brothers and Doscher entries in August and November, 1898, which are denoted by the two vertical lines. The third vertical line marks the end of the price war in June, 1900.

\subsection{Pricing below marginal cost}

Figure 2 graphs the proper margin, i.e., the net of raw sugar costs margin ( $P$ $\left.1.075 \times P_{R A W}\right)$, from the start of 1898 until the end of 1900. It adds horizontal lines at $26 \phi$ and $16 \phi$ to designate our best and lower estimate for $c_{o}$, the non-raw sugar cost of refining. In the aftermath of entry, the proper margin fell into and even below this range, indicating pricing below marginal cost.

This state of affairs did not escape comment by contemporary industry experts. In the early weeks of the war, Willet and Gray state "The present difference between raw and refined sugar is reduced this week to 47 cents. ... Anyone familiar with the amount of raw sugar [...] required to produce $100 \mathrm{lbs}$. [refined] does not require to be told that there is an actual loss to refiners at 47 cents difference." ${ }^{34}$ This difference was subsequently reduced further.

How, then, did Zerbe argue that ASRC did not suffer out of pocket losses from this price war? His cost figures are similar to ours, but he examines the margin between raw and refined sugars only at an annual frequency, for the years

\footnotetext{
${ }^{34}$ Willett and Gray, October 20,1898 , p. 5.
} 
1898-1900. In 1899 this was a new low of 50\%, which was consistent with zero (variable) profits. But as our evidence demonstrates, for several months ASRC priced below marginal cost. Our higher frequency data are the more appropriate, since ASRC set prices on a weekly, if not daily, basis.

We speak of ASRC setting the price, since, logically, the price war was entirely of its making. Because ASRC had enough capacity to satisfy the entire market, a rival who set a price above the ASRC price would make no sales - as twice happened to the Howell refineries. A rival could gain by setting a price below ASRC's price only if it were not already capacity constrained. Even then, it could certainly not force ASRC to lower its price below the dominant firm price level. The sequencing of price cuts is consistent with this logic. Only once did Arbuckle Brothers lead ASRC in cutting price. As Willett and Gray report: "That the war is one sided is shown by the fact that all the independents simply follow the moves of [ASRC] either up or down and attempt no leading aggressive moves." ${ }^{35}$

If ASRC was pricing below marginal cost, why did the prey continue to produce? Several times the incumbent independent refineries, principally the Mollenhauer, did shut down or ran at "minimum capacity". ${ }^{36}$ Nevertheless, there were periods with price below marginal cost in which they continued to produce, for a couple of reasons. Month-long contractual obligations and the value of a reputation for assured supply may lead firms to produce at a current loss. ${ }^{37}$ Also, shut-down costs will drive a wedge between the margins at which it is optimal to shut down and start up production. The reports of firms running at "minimum capacity" indicate that such costs existed. Changing expectations of the future paths of prices will have made the shut-down and start-up margins variable, and so prevent us from identifying a single value of the proper margin at which shutdown occurred or production resumed. Nevertheless, it is telling that the minimum proper margin above which the incumbent independent refiners always produced was $26 \%$.

The one non-ASRC firm that never shut down was Arbuckle Brothers. Even the Doscher refinery, which was constructed contemporaneously, with the same capacity, and, presumably, the same technology as the Arbuckle Brothers' plant, significantly curtailed its production in the late stages of the war. ${ }^{38}$ Arbuckle

\footnotetext{
${ }^{35}$ Willett and Gray, November 17, 1898.

${ }^{36}$ See Willett and Gray, November 17, 1898, February 2, 1899, October 5, 1899, January 25, 1900 , February 23, 1900.

${ }^{37}$ The importance of assured supply is revealed in the contest between Arbuckle Brothers and ASRC for retailers in New England.

${ }^{38}$ Willet and Gray, May $17,1900$.
} 
Brothers' advantage lay ultimately in its packaging machine. Its packaged sugar earned a premium of $6 \phi$ at the retail level, ${ }^{39}$ thus giving the firm substantial, but incomplete, protection from ARSC's below-cost pricing - incomplete, because, as Figure 2 shows, price fell below cost at times an amount greater than the premium, and because most of its sugar in this period was sold unpackaged, in barrels. But the factors that led the other fringe firms to produce during the price war would have been especially relevant as well to Arbuckle Brothers - a new entrant whose packaging machine promised it a bright future in the industry .

In explaining why the fringe firms did not fully shut down during the price war, we have introduced additional benefits and costs not covered by price and our estimate of $c_{o}$-shutdown and start-up costs, reputation, the value of packaged goods, and so forth. These considerations do not invalidate the comparison of the proper margin to $c_{o}$ as a sufficient condition for predation. The essential element of predation is that the incumbent firm price below the competitive level, of which a price below its own cost is sufficient evidence. The premium for packaged sugar was, of course, relevant to Arbuckle Brothers' profit calculus only, not ASRC's. Furthermore, the value of reputation and shutdown and start-up costs might lead a firm to tolerate a price below manufacturing cost for a time, not to choose it.

\subsection{A Lower Bound on Competitive Prices}

Zerbe rejects the predatory interpretation of this episode, instead attributing the sharp drop in prices with Arbuckle Brothers' entry to the breakdown of a previously existing cartel (p. 360). He attributes the price war with a return to competition, which he associates, in turn, with a price that equals marginal cost. That logic, however, casts ASRC as a price taker, an absurd role for a firm with nearly eighty percent of industry capacity.

A more reasonable definition of competitive conduct is the noncooperative static equilibrium. We showed in Section 3.3 that, with rival firms capacity constrained, the noncooperative equilibrium price exceeds marginal cost. As a test for predation, then, a price below marginal cost is sufficient but not necessary.

In this section we offer a second, independent line of reasoning, that substitutes knowledge about industry demand and capacity for cost information. Employing estimates of industry demand parameters from Genesove and Mullin (1995), we calculate the dominant firm price, $p^{d}$ both before and after entry. We find that observed prices fell too low to be the product of dominant firm pricing in the face

${ }^{39}$ Willet and Gray, August 25, 1898, December 1, 1898 and February 16, 1899. 
of enlarged fringe capacity.

The dominant firm price $p^{d}$ is of course a function of not only demand and fringe capacity but cost as well. To eliminate uncertainty over $c_{o}$ as a source of scepticism over our results, we calculate $p^{d}$ at both $c_{o}=26 \phi$ and zero. By undervaluing marginal cost, the calculated $p^{d}$ at $0 \phi$ will underestimate the true dominant firm price, and so bias our results against the conclusion that prices were too low to be rationalized by competition. Furthermore, we focus on the predicted dominant firm price for the period after both Arbuckle Brothers and Doscher had entered, which represents a local maximum of fringe capacity.

The easiest case to consider is linear demand. (The results are quite similar for exponential, quadratic and log-linear demand) With a fringe capacity of $K_{f}$ and market demand curve

$$
D(P)=\underset{(1.46)}{12.36}-\underset{(0.36)}{1.97} P
$$

(and so ASRC residual demand curve $D^{d}(P)=12.36-K_{f}-1.97 P$ ),${ }^{40}$ the dominant firm price is

$$
p^{d}\left(c_{o}\right)=\left\{\frac{12.36-K_{f}}{1.97}+1.075 P_{R A W}+c_{o}\right\} / 2
$$

and so the predicted proper margin under dominant firm, or Cournot, pricing is

$$
P M^{d}\left(c_{o}\right) \equiv p^{d}\left(c_{o}\right)-1.075 P_{R A W}=\frac{12.36-K_{f}}{1.97}+\frac{1}{2} c_{o}-\frac{1.075}{2} P_{R A W}
$$

Under Bertrand competition, price will fluctuate randomly between $p^{d}$ and $\underline{p}$, defined in Section 3.3. For the linear demand curve,

$$
\underline{p}\left(c_{o}\right)=p^{M}\left(c_{o}\right)-\sqrt{\left(p^{M}\left(c_{o}\right)-\left[1.075 P_{R A W}+c_{o}\right]\right)^{2}-\left(p^{d}\left(c_{o}\right)-\left[1.075 P_{R A W}+c_{o}\right]\right)^{2}}
$$

where $p^{M}\left(c_{o}\right)=\left\{\frac{12.36}{1.97}+\left[1.075 P_{R A W}+c_{o}\right]\right\} / 2 .{ }^{41}$ Let $\underline{P M}\left(c_{o}\right) \equiv \underline{p}\left(c_{o}\right)-1.075 P_{R A W}$.

\footnotetext{
${ }^{40}$ Price is in cents per hundred pounds, while production is in hundred of thousands of long tons per quarter. Standard errors are in parantheses. The demand curve is estimated quarterly over 1890-1914 by instrumental variables, with Cuban imports as the instrument, as in Genesove and Mullin, except there is no control for season here. The logic for using Cuban imports, which was an inframarginal supply of raw sugar at the time, is laid out in Genesove and Mullin.

In constructing the residual demand curve, we assume, as throughout, that the rationing rule is efficient. The competitive price would be higher under a proportional rationing rule.

${ }^{41}$ Let $\Delta \equiv p^{M}-p$. Simple algebra shows that $\pi(p)=1.97\left(p^{M}-c-\Delta\right)\left(p^{M}-c+\Delta\right)$, and $\pi^{d}=1.97\left(p^{d}-c\right)\left(p^{\frac{\bar{d}}{d}}-c\right)$. Then, since $\pi(\underline{p}) \equiv \pi^{d},\left(p^{\bar{M}}-c\right)^{2}-\Delta^{2}=\left(p^{d}-c\right)^{2}$
} 
Figure 3 plots the observed proper margin, $P M^{d}$, and $P M$, by assumed value of $c_{o}$ It is clear that during the period of the price war the observed proper margin lay well below the predicted competitive proper margins, even under the assumption of $c_{o}=0$. The exception is the summer of 1899 , in which the actual and the predicted dominant firm proper margins are very close. This is the same period in which the proper margin is seen to exceed $26 \phi$ in Figure 2. We return to this issue in the next subsection.

The behavior of the proper margin outside of the price war period is also interesting. It suggests competitive (Bertrand) pricing before Arbuckle Brothers' entry, and either competitive or supracompetitive prices after the agreement. This behavior is consistent with the reports that the fringe firms were producing at capacity before, and that Arbuckle Brothers was restricting its output after, the price war. It is inconsistent with Zerbe's claim of collusive prices before the price war.

\subsection{Price War Respite}

The margin varied over the price war, and did not always hover at the point of zero profits. Figure 2 shows that the price war was interrupted in 1899 by the summer months. Indeed, Figure $3 \mathrm{~b}(?)$ shows that the proper margin just exceeds $P M^{d}(26 \phi)$ at its peak. This was the period of peak sugar demand, due to the complementarity between sugar and fruit in fruit canning (Genesove and Mullin (1995)).

Why did ASRC temporarily halt the price war? The answer is related to the traditional critique of the rationality of predation that the predator, because it is larger, must suffer more than the prey. Because ASRC was not capacity constrained, even in high season, its effective size changed seasonally, and therefore so did its cost from preying. From our previous work we know that on average the proper margin was higher in high season than in low (53ф versus $46 \phi)$, and that production was $20 \%$ higher in high season than in low $(511,000$ long tons in the third quarter versus an average 420,000 in all other quarters). Both because of the higher margin and the higher output, ASRC sacrificed more flow profits in high season than in low season by failing to price above marginal cost.

Of course, the fringe's profits were normally higher in the high season than the low season. If a price war is meant to drain the entrant of its cash reserves or deny it profit flows, its greatest gross return is when the entrant's competitive profits are greatest. But it is easy to see that ASRC would gain more from a high season 
respite than Arbuckle Brothers did. With ASRC producing more than Arbuckle Brothers, a higher margin would benefit it more than the latter in absolute terms, though the proportional effect would be the same. And with Arbuckle Brothers capacity constrained, all the increase in demand would go to ASRC.

We operationalize the revealed willingness to pay for predation by computing a loss ratio - the ratio of ASRC's loss from the price war to the loss suffered by its rivals. The cost to continuing the price war at any point in time was the excess of non-predatory profits over predatory profits. Non-predatory profits we take to be fully accommodative - in the sense of ASRC restrict its output one for one with the capacity of the entrant, thus maintaining the price. ${ }^{42}$ As an initial simplification, we assume that the predatory strategy called for marginal cost pricing, so that predatory profits for all firms were zero. Since all firms face the same price cost margin, the loss ratio then simplifies to ASRC's non-predatory output, divided by the capacity of the entrant. Non-predatory output, which we label $\hat{Q}$, is, of course, a counterfactual; we measure it by the predicted value from a regression of weekly meltings on seasonal variables (the sine and cosine defined over the week with an annual frequency) and a time trend. Letting $K_{f}$ indicate total fringe capacity, we then construct ASRC output as $\hat{Q}-K_{f}$. Our initial value of the ratio of the incumbent and rival losses, is therefore $L R_{1}=\left(\widehat{Q}-K_{f}\right) / K_{e}$, where $K_{e}$ is the entrant's capacity. $K_{e}$, and so $K_{f}$, change abruptly with the entry of Arbuckle Brothers, and then Doscher, and change gradually over a month or two after entry as effective capacity increased as equipment was tested and adjusted.

Figure 4 displays $L R_{1}$ and the proper margin (multiplied by ten for comparability) over the duration of the Arbuckle War. At the beginning of the price war, with the proper margin near or below 16\%, our lower measure of marginal cost, $L R_{1}$ is very high and then falls sharply. Mechanically, the high value of $L R_{1}$ is due to the low initial capacity of the Arbuckle Brothers plant. But its economic meaning is that predation at this early stage was a very costly undertaking. The countervailing benefit must have been high as well, perhaps because predation at the point of initial production could persuade the entrant to abandon its efforts, or persuade wholesalers not to switch refiners.

$L R_{1}$ reaches its maximum during the respite. The proper margin series demonstrates the existence of the respite. The loss ratio helps account for it. The respite occurs because the cost of continuing to price at marginal cost had grown too high.

\footnotetext{
${ }^{42} \mathrm{~A}$ dominant firm strategy under linear demand would have ASRC restricting its output by only half a pound for every pound of the entrant's capacity, thus lowering price. The results for this alternative counterfactual are qualitatively the same as those presented in the text.
} 
The price war pauses and then resumes when $L R_{1}$ is near 4 . Thus, at that stage of the war, ASRC was willing to pay $\$ 4$ to reduce Arbuckle and Doscher's profits by $\$ 1$, but was not willing to pay more than that. The demand for predation is downward sloping!

These initial calculations falsely assume that predatory prices were set at marginal cost. To correct for that, we subtract from the usual profits the actual profits of ASRC and the entrants, under the assumption that all fringe firms produced at capacity. We therefore calculate a second loss ratio

$$
L R_{2}=\frac{\$ 0.43\left(\hat{Q}-K_{f}\right)-(p-c)\left(Q-K_{f}\right)}{\$ 0.43 K_{e}-(p-c) K_{e}}
$$

where $Q$ and $p-c$ are the observed industry output and price-cost margin, the latter under the assumption that $c_{o}$ is $26 \phi$. We multiply the counterfactual output levels by the $43 \phi$, the average real margin from $1893-1897$, the years between our major entry episodes. Figure 5 displays $L R_{2}$. The pattern is very much like that of $L R_{1}$.

\section{Claus Spreckels, Senior}

In discussing this episode, we must rely largely on Eichner's account. The oldest copies of Willett and Gray that we could obtain are from 1891, the middle of the Spreckels war, ${ }^{43}$ while the negotiations between Spreckels and ASRC were conducted under strict secrecy, with many details left unrevealed until the ASRC monopolization trial in 1912.

Spreckels' entry may have been motivated not only by the prospect of profits on the East Coast, but by the opportunity to retaliate for the Sugar Trust's incursion into his California territory. During this period, the West Coast constituted a largely separate market from the East Coast, where sugar production was concentrated. ${ }^{44}$ In early 1888 , the Sugar Trust, which was composed of East

\footnotetext{
${ }^{43}$ Eichner was able to examine earlier issues in the offices of Willett and Gray, but that publication has since gone out of business.

${ }^{44}$ This separation was due to the relative costs of water and land transportation. Refineries were located near the ocean in order to be able to receive imported raw sugar directly into their warehouses. Once refined, sugar is subject to a deterioration risk from prolonged exposure to moisture, ruling out ocean transport, and so sugar was shipped into the nation's interior by means of rail or rail/barge combinations. Consequently, there was potential competition between East and West coast refiners for business near the Missouri and Mississippi rivers, but
} 
Coast and Louisiana plants, acquired a West Coast plant, in apparent violation of an understanding between Spreckels and the Trust about a division of markets. Shortly thereafter, Spreckels announced his intention to enter the Eastern market, and construction of a plant in Philadelphia began in May, 1888. Spreckels' initial capacity was 3000 barrels per day, but even before initial production, he made plans to double its capacity by duplicating the whole of the refinery's buildings. ${ }^{45}$

Figure 6 shows the proper margin from 1882 through the end of 1892. As before, these are the New York prices. The two vertical lines designate the formation of the Trust and Spreckels' entry. The Trust's formation in late 1887 sparked

a sharp rise in refined prices, which then declined with the beginning of sizeable production in Spreckels Philadelphia plant in early 1890.

The aftermath of the Spreckels entry is apparent from Figure 7 which shows the (nominal) proper margin for 1889-1892, inclusive. We graph the unadjusted, nominal values of the proper margin to avoid introducing discontinuous changes from the use of an annual, general price index. The horizontal lines are the 1890 dollars equivalent of our estimates of $c_{o}$ : a best estimate of $31 \phi$ (26 $\phi$ in 1898 dollars), with $19 \notin(16 \phi)$ as a lower bound. The two vertical lines designate Spreckels' first, minimal production on December 9, 1889, and the acquisition of the Philadelphia refiners on March 4, 1892.

The proper margin fell sharply at the end of 1889 , and hovered at or below marginal cost for most of 1890 , rising well above marginal cost only for a respite in high season. War conditions carried into 1891, although the decrease in raw sugar costs, consequent upon the abolition of the substantial tariff on raw sugar in April, led to a considerable increase in the proper margin. By November the margin was again declining. Spreckels Philadelphia plant and the remaining independent Philadelphia refiners were acquired by ASRC in February and March, 1892. Within a month, the proper margin increased substantially.

\subsection{Pricing below marginal cost}

As Figure 7 indicates, the proper margin was below our estimate of $c_{o}$ for a considerable number of weeks during the Spreckels war, indicating pricing below marginal cost. As in the Arbuckle war, this pricing behavior was noted by Willett and Gray. In January 1892 they reported that "there is a considerable loss of

otherwise their markets did not overlap. The United States population was then much more concentrated on the East Coast than now.

${ }^{45}$ New York Times, August 4, 1889 and December 28, 1889. 
refining, owing to the renewed competition between" the ASRC and the Philadelphia refiners. ${ }^{46}$ They even quantified the loss as $10 \%$ per hundred lbs, which given prevailing prices implies a nominal value of $c_{o}$ of $28 \phi$, close to our 1890 value of $31 \phi$, and well within our range of estimates. ${ }^{47}$

\subsection{Price War Respites}

As in the Arbuckle war, the high season brought about a respite in the price war. In 1890, the proper margin rose from $23 \phi$ on May 21 to 80 cents on June 11. The respite was brief, however, with the proper margin falling to $21 \phi$ at the end of July. The explanation for this respite is the same as before: predation was relatively more costly for ASRC in high than low season. We reiterate that this does not represent peak load pricing, as ASRC retained excess capacity even in high season.

The proper margin rose in the spring and summer of 1891 as well. The usual high season respite argument applies here, as well, but there are two confounding forces. The McKinley Tariff, which included the abolition of duties on raw sugar, took effect on April 1, 1891. The impact on the raw sugar market was dramatic, with the New York price of raw sugar falling from $5.68 \phi$ to $3.53 \phi$ per pound. As equation (1) indicates, decreases in the price of raw sugar lead to increases in the competitive proper margin, thus increasing the cost of predation for ASRC. The runup in the proper margin is also coincident with an initial rapprochement between ASRC and Spreckels. This is evidenced by recorded payments by the ASRC West Coast plant to JD Spreckels and Brothers, a shipping concern operated by Spreckels' sons, that begin at seventy thousand dollars in January 1891 and increased to two hundred thousand. ${ }^{48}$ This initial agreement between Spreckels and ASRC is more fully discussed immediately below.

\subsection{ASRC-Spreckels Peace Process}

Early in 1891 ASRC offered to sell Spreckels its West Coast plant if Spreckels would sell it "a half interest in the Philadelphia concern." 49 Spreckels rejected this offer, but subsequent negotiations resulted in the formation of a holding

\footnotetext{
${ }^{46}$ Willett and Gray, January 14,1892, p. 3.

${ }^{47}$ Deflating 31 cents by the 1892 value of our price index, we obtain 29 cents.

${ }^{48}$ Spreckels Financial Records, Bancroft Library, University of California, Berkeley.

${ }^{49}$ This account comes from Spreckels Jr.'s 1912 testimony in tlie ASRC monopolization case, cited by Eichner, p. 165.
} 
company, The Western Sugar Refining Company, which was equally owned by Spreckels and ASRC and which leased the two companies' West Coast plants. In return, Spreckels sold a 45 percent equity stake in his Philadelphia plant to Henry Havemeyer, ASRC's president for $\$ 2.25$ million.

In rejecting the initial offer but accepting the final agreement, Spreckels sacrificed half of the West Coast monopoly in return for an additional 5 percent stake, and therefore control, of his Philadelphia plant. Retaining an East Coast presence ensured multimarket contact in case ASRC should cause further problems on the West Coast. The final arrangement also reduced ASRC's incentive to reenter in the West at some future date from (per-firm) duopoly profits, had it sold its West Coast plant outright, to the lesser amount of one and a half times (per-firm) duopoly profits minus half monopoly profits under the final arrangement. We do not know the sale prices that would have attached to the asset transfer in the initial offer, but Spreckels apparently objected to the proposed reallocation of asset control, not simply to the transfer price.

Although the creation of the Western Sugar Refining Company became public knowledge by the spring or summer of 1891, the other arrangements remained a secret, although rumors of a detente were afoot. Most of these rumors seemed to have had as their basis the respite in the price war the summer of $1891 . .^{50}$ Spreckels continued to deny that any deal had been struck. ${ }^{51}$

Because of frictions over the running of the Philadelphia plant, ASRC began discussions with Spreckels in the fall of 1891 about buying out his majority share in the Philadelphia operation. ASRC kept both these discussions and Havemeyer's minority stake secret. The concern for secrecy was well-founded; ASRC wished to purchase the four remaining independent Philadelphia refiners, and the terms of the buyout would be higher if these refiners anticipated Spreckels' acquisition.

The final acquisition of Spreckels and the other Philadelphia refiners was worked out from late 1891 to early 1892, and became public in March, $1892 .^{52}$ As Figure 7 shows, the proper margin fell in October 1891, and reached at or below marginal cost in early 1892 . This decline can be interpreted as a predatory act designed to aid the acquisition of these other refiners. If ASRC's minority stake would have assured continued peace with Spreckels, then the foregone prof-

\footnotetext{
${ }^{50}$ The first mention of the Western in the ledger books of ASRC's West Coast plant is on April 15. Willett and Gray, August 27, 1891 report that although there is no factual basis for the rumors that Spreckels has been acquired by ASRC, they have reached some sort of arrangement, as evidenced by the advance in refined prices.

${ }^{51}$ New York Times, August 27, 1891.

${ }^{52}$ Eichner, pp. $169-173$.
} 
its during the resumption of the price war represent a predatory investment which yielded the acquisition of the four independent Philadelphia refiners. By this act, the other refiners were led to believe that active competition with Spreckels was likely to continue for some time, implying poor profit prospects for themselves. ${ }^{\mathbf{5}}$

The Philadelphia acquisitions raised ASRC's capacity share to 95 percent. ASRC wasted little time in earning a return on its investment, increasing the proper margin from $25 \phi$ in late February, 1892, to $92 \phi$ in late March, as displayed in Figure 7. The proper margin fluctuated around this higher level until the end of 1894.

\section{Was Predation Profitable?}

To answer that question, we need to understand how predation actually works. One explanation, that the price wars were aimed at driving the newly added capacity itself out of the industry, can be rejected outright. That capacity was in the industry to stay. The expenditure on the plant was sunk, and though the original owners could themselves exit the industry, the salvage value of a sugar refinery plant was very small. ${ }^{\mathbf{5 4}}$

Thus ASRC's goal must have been some outcome short of removing the new assets from the industry. We consider three possible objectives: a lower purchase price for the entrant's plant, a greater market share in a collusive equilibrium, and the deterrence of entry of additional capacity. We evaluate each on of these theories by calculating an internal rate of return for predation. We restrict our

\footnotetext{
${ }^{53}$ Eichner indicates that many of the independent Philadelphia refiners did not know of Haveymeyer's minority stake in Spreckels's Philadelphia plant even after they sold out, learning of it only in 1912 testimony. Willett and Gray's report of January 21, 1892 noted a belief that a minority interest in Spreckels had passed into hands friendly to ASRC in early 1891 when the California combination occurred. They concluded, however, that such an interest had been insufficient to soften competition, so that the profit outlook for 1892 was grim.

${ }^{54}$ See Section 3.2. Compare the British shipping cartels at the turn of the century. In that industry, costs, at least on any particular shipping route, were not sunk, and so predation could hope to remove new capacity from a particular route, as Scott Morton (1996) has argued. At the opposite extreme, the Joint Executive Committee, a 19th century railroad cartel, accommodated entrants by allocating them a share of cartel business. According to Porter (1983), this policy was dictated by the sunk costs associated with the railroad industry, as reinforced by the prevailing bankruptcy law. Debts incurred by a bankrupt railroad could be effectively dismissed by the receivership court, allowing the incumbent management to reorganize the railroad and set rates as low as necessary to generate traffic. Thus predation could neither remove the capacity nor alter the control of it.
} 
attention to the Arbuckle Brothers episode.

Yamey (1972) argued that "A bout of price warfare initiated by the aggressor ... might serve to cause the rival to revise its expectations and hence alter its terms of sale to an acceptable level". In Saloner's (1987) formalization of this argument, an incumbent firm signals that it has low costs by pricing low. Since the entrant's profits are decreasing in the incumbent's costs, proof that an incumbent has low costs will lower the minimum price that the entrant would be willing to accept in a buyout. Assuming that an entrant produces at capacity (as in the dominant firm equilibrium), that price would be the net present value of $\left(p-c_{e}\right) K_{e}$, where $c_{e}$ is the entrant's cost and $K_{e}$ its capacity. By this logic, the gross per-period return to ASRC of predation was $K_{e} \Delta c \frac{d p}{d c}$, where $\Delta c$ is the difference between high and low cost, and $d p / d c$ is the responsiveness of price to increases in the incumbent's cost in non-predatory periods.

Signalling cost by a sudden cut in price might seem an unconvincing strategy for an incumbent that has been setting prices daily for several years before entry, although it might be argued that price is more revealing about cost the more competitive the circumstances. What ever the case, the plausible range of an entrant's beliefs about ASRC's costs is too small to justify a signalling explanation. Although we do not know what the precise beliefs were, we do know that the actual cost differences across firms were small. The Industrial Commission of 1897 was told that: "it is possible that the ASRC, or the Havemeyer \& Elder house and the Spreckels house at Philadelphia can refine at a smaller margin than the others. ... [but] it can [not] amount to a great deal; I suppose 3 to 5 cents a hundred [pounds] would perhaps represent the difference." 55 Several industry participants testified before the Hardwick Committee in 1911 that the "full cost of refining" was between 60 to $65 \phi$, indicating a cost range of $5 \phi$ per hundred pounds (3.75\& in 1898 dollars). Using the higher real $5 \&$ figure for $\Delta c$, a value of .93 for $d p / d c$ (from our estimate of the response of the refined price to the raw

\footnotetext{
${ }^{55}$ James Post, $I C$, Volume I, Part 2, 1900, p. 151. The cost range in the U.S. Tariff Commission's survey of refining plants is much larger than these figures. The gap in the average non-sugar costs of the costliest and least costly plant in 1917 was 35 cents, or 17 cents in 1898 dollars. There are a number of reasons to expect the higher range. First, this survey included all U.S. plants, not simply the East Coast ones. Second, 1917 was an inflationary year, so differences in the distribution of production over the year across plants could induce differences in measured costs. Finally, production took place under government regulation due to the war, and this may have generated true cost heterogeneities that would not have occurred in a market environment. Even the higher range would predict an internal rate of return of only 2.6 percent. U.S. Tariff Commission, Refined Sugar: Costs, Prices and Profits, Washington 1920.
} 
price, from Genesove and Mullin (1995), adjusted for the loss in sugar refining), and an Arbuckle Brothers capacity of one million pounds per day, we obtain a yearly gross return of $(365$ million $l b.) \times 0.05 \phi / l b . \times .93=\$ 169,725$. Compared to a gross loss (the difference between its non-predatory profits and its actual profits) of $\$ 21.84$ million dollars for ASRC over the predation period, this implies an internal rate of return to predation of $\$ 169,725 / \$ 21,840,000$, or a mere 0.77 percent. ${ }^{56}$

Alternatively, the price war may have constituted a bargaining game over the share of collusive profits. As we have noted, there is a range of fringe output that is sustainable as part of a collusive equilibrium. Under this interpretation, the most ASRC could have hoped to gain from predation would be the difference between Arbuckle Brothers' part of collusive profits when producing at capacity and the latter's competitive profits. The collusive price-cost margin could not have been expected to be greater after entry than before, so we will again set that at 43\%. Fringe competitive profits are lowest under Bertrand competition, when it is equal to $K_{e}(\underline{p}-c)$. Thus ASRC's maximum possible gain was bounded from above by $K_{e}(43 \bar{d}-(p-c))$. During the price war, the Lower Bertrand proper margin averaged $39 \phi$ (also its average over the 1900-1914 period.) Thus an upper bound for the gain is $(1,000,000 l b s . \times 365) \times 0.04 \phi=\$ 146,000$, or an internal rate of return of only 0.67 percent.

Might ASRC having been attempting to establishing a reputation for toughness so as to dissuade the entry of additional fringe capacity? To assess the profitability of such a strategy requires knowledge of the supply of potential entering capacity with and without predation by ASRC. A natural candidate for the former is the actual entry that occurred after the end of the Arbuckle Brothers' price war. Between June 1900 and August 1914, an average of 1040 barrels per day (bpd) of additional fringe capacity entered the industry every year.

We calculate the internal rate of return for predation according to the reputation hypothesis as that interest rate such that the difference between ASRC's dominant profits given an entry flow contingent on predation and that given an entry flow contingent on no predation equals its gross loss of $\$ 21.84$ million. This calculation requires an assumed price of raw sugar, and an initial fringe capacity level. We consider raw sugar prices of $3.0 \phi$ (the post entry average), $3.35 \phi$ (the 'interwar' average - and our preferred value) and $3.5 \phi$ (the average over 1890-

\footnotetext{
${ }^{56}$ In all our calculations of an internal rate of return, we assume that all losses are incurred in the first, predatory, period, and this investment is then followed by a perpetual stream of identical benefits per period, which gives rise to our simple formula.
} 
1897). As initial fringe capacities, we consider $14,100 \mathrm{bpd}$ - fringe capacity once Arbuckle Brothers and Doscher had reached planned capacity, and 9,200 bpd the capacity of the fringe less that of the National consolidation in June 1900 (which was under the control of ASRC's president). ${ }^{57}$

The Table presented below shows our results. Predation was clearly profitable if, without it, one or two 3000 bpd plants would enter a year. Although that was the rate of entry experienced at the time of the price war, we doubt that ASRC could have expected it to continue; after all, Arbuckle Brothers was a special case. On the other hand, had ASRC expected a return to the entry rates in the 1892-1897 period, which was 1125 bpd a year, then predation would been clearly unprofitable.

More reasonable no-predation entry rates are 1600 or $1840 \mathrm{bpd}$, which were the average entry rates between the March 1892 consolidation up to, and including, the entries of Arbuckle Brothers and Doscher. Interestingly, at these rates, predation could be justified, but only if ASRC had anticipated e consolidating the pre-existing fringe firms into the National.

Internal Rate of Return of Predation: Reputation Hypothesis Initial Fringe Capacity

Additional Yearly Capacity
without Predation
1125
1600
1840
3000
6000

\begin{tabular}{|c|c|c|c|c|c|}
\hline & & Frin & $\mathrm{Ca}$ & & \\
\hline & $9, \overline{200}$ & & & 14,100 & \\
\hline & & taw Sug & Ir Price & & \\
\hline $\begin{array}{c}3.0 \phi \\
0 \%\end{array}$ & $\begin{array}{c}3.35 \phi \\
0 \%\end{array}$ & $\begin{array}{c}3.5 \phi \\
0 \%\end{array}$ & $\begin{array}{c}3.0 \phi \\
0 \%\end{array}$ & $\begin{array}{c}3.35 \phi \\
0 \%\end{array}$ & $\begin{array}{c}3.5 \phi \\
0 \%\end{array}$ \\
\hline $11.2 \%$ & $6.6 \%$ & $3.2 \%$ & $0.4 \%$ & $0 \%$ & $0 \%$ \\
\hline $14.8 \%$ & $10.0 \%$ & $6.6 \%$ & $3.2 \%$ & $2.0 \%$ & $0 \%$ \\
\hline $28.2 \%$ & $19.7 \%$ & $15.6 \%$ & $20.6 \%$ & $9.5 \%$ & $3.6 \%$ \\
\hline & $33.1 \%$ & $26.2 \%$ & $34.0 \%$ & $17.9 \%$ & \\
\hline
\end{tabular}

A final explanation is the "long-purse" hypothesis. In this view, of which Bolton and Scharfstein (1990) and Fudenberg and Tirole are variants, new entrants are typically financially constrained, so that predation serves to hinder

${ }^{57}$ We assume that entry stops when fringe capacity has reached its long-run level - that level such that dominant firm price just equals the sum of marginal production cost and the annuatized per unit cost of capacity. Calculation of the long run capacity level requires an assumption of the unit cost of capacity. In the calculations we present, we assume a cost of $\$ 2$ per hundred pounds - corresponding to the cost of physical capital discussed in Section Y. The results were invariant to the choice of two other numbers - zero and $\$ 4$ per hundrend pounds a day (to include working capital). 
their expansion. If every dollar of profits denied the Arbuckle Brothers would have gone to capacity expansion, then the additional capacity thus deterred was 812,500 pounds per day. This is obtained by dividing the Arbuckle Brothers' price war losses of $\$ 3.25$ million by the four dollars required in physical and working capital to increase capacity by one daily pound. To a first approximation, every unit increase in the fringe's capacity reduces ASRC profits by the price-cost margin. ${ }^{58}$ Using the pre-price war average margin of $43 \notin$ per hundred pounds, this translates to a yearly gross return to predation of $(365 \times 812,500 l b s.) \times 0.43 \phi / l b .=\$ 1.275$ million. When compared to ASRC's price war losses of $\$ 21.84$ million, we obtain an internal rate of return of 5.8 percent.

\section{Conclusion}

Whatever the profitability of the observed predation after the Arbuckle Brothers' entry, over the quarter century following the formation of the Sugar Trust, ASRC and its predecessor seem to have been rather unsuccessful in deterring entry. Could it have done better?

It is perhaps surprising that we see no strategic activity by ASRC in the period before an entrant's plant is completed, when the prospective cost savings from halting construction would have given the entrant a greater incentive to abandon the entry attempt. The multiple stages of entry - the announcement of intent, the purchase of land, and the actual construction over a year or two gave ASRC ample opportunity to identify the imminency of entry, and so focus its deterrent activities on an identified entrant at a particular point in time.

There was, however, little that ASRC could have done to thwart entry at this stage. The standard ploy recognized by the deterrence literature is to accumulate excess capacity. Because adding capacity to existing plants typically takes much less time than building a new plant, as Lieberman (1987) in particular has emphasized, ASRC might have met an entrant's announcement and start of plant construction by increasing its own capacity. But at the time of the 1887 consolidation, ASRC already had enough capacity to accommodate the entire market at marginal cost, ${ }^{59}$ so that additional capacity accumulation would not have been a

\footnotetext{
${ }^{58}$ This comes from a standard application of the envelope theorem to ASRC's dominant firm profits of $\pi(K)=\max _{p}[(p-c)(D(p)-K]$. The price cost margin overestimates the fall in profits as it ignores the opportunity to adjust the price optimally.

${ }^{59}$ Assessments by both market observers and participants make that clear. For example, Havemeyer testified in the midst of the Arbuckle Brothers war that ASRC's capacity was $20 \%$
} 
credible threat.

Nor could ASRC have used long term contracts with buyers to foreclose entry. That would have been a monumental task, given the number of small grocers who sold sugar for consumer use. Foreclosure through contracts with brokers would surely have failed as well, given the ease of entry into brokerage. The Arbuckle Brothers' leapfrog over wholesalers in New England to deal directly with retailers during the price war shows that intermediate distribution stages did not constitute insurmountable bottlenecks. ${ }^{60}$ Nor would a strategy of long term contracts with large buyers, such as the fruit canners, have been successful. That demand was concentrated in the summer months, when overall demand was high, so that locking those buyers in would not have locked out entrants.

Indeed, waiting for an entrant to actually produce refined sugar before taking costly predatory actions, or making acquisition overtures, is a sensible way to screen an entrant's capabilities. Not every constructed plant was a workable one. Adolph Segal's Camden plant, which ASRC bought from him for about $\$ 50,000$ to $\$ 100,000$ above his construction costs, reportedly had an inadequate water supply, and was therefore inoperative. ${ }^{61}$ Segal was a business promoter with no prior experience in the sugar refining industry, but a history of constructing plants which he would then sell to the dominant firm in the industry. ${ }^{62}$

Upon completion of the plant, some entrants were fought and some accomodated. ASRC's response is fully predicted by the entrant's size. Spreckels Sr., Arbuckle Brothers and Doscher all entered with 3000 barrels per day plants, and all were met with drastic reductions in price. The rest entered with plants half that size or less, and were accomodated. The seasonal respites during the price wars suggest an obvious explanation - the cost of predation, measured as the ratio of the predator to prey's losses, is greater the smaller the entrant. These small entrants were practicing Judo economics, to use Gelman and Spelman's (1983) phrase.

On the other hand, the resolution of ownership depended on the motive for entry. Those entrants which because of cross-market considerations had a strategic reason to enter were immediately preyed upon, but remained in the industry after the predatory period. This group consists of Arbuckle Brothers, for which entry

greater than the current market "demand" (IC, Volume I, Part 2, p. 107). Also, see footnotes 3.2 and 5.2 .

${ }^{60}$ Eichner, p. 219.

${ }^{61}$ Zerbe, p. 283 and 356.

${ }^{62}$ Eichner, p. 282. 
constituted backward integration, and Spreckels $\mathrm{Sr}$., for whom it was multi-market retaliation. The remaining entrants - the entrants of the mid-1890s, Doscher, Segal and Spreckels Jr. - had no other assets connected in any way to the sugar industry at the time of entry, though they may have had some prior experience in the sugar industry. They entered solely in the pursuit of profits from their newly constructed plants. They were accommodated, but eventually purchased or otherwise reconciled with ASRC.

The contrast between the final outcome of the near simultaneous Doscher and Arbuckle Brothers entries is instructive. Technologically, the two plants were nearly identical. Built within four months of each other, each took 20 months to produce its first sugars, and each had a capacity of 3000 barrels per day. But strategically, the entrants were quite distinct. Doscher was motivated solely by profits from refining sugar. The product differentiation inherent in pre-packaged goods gave Arbuckle Brothers some degree of market power; and so it had the additional goal of securing refined sugar at marginal cost to avoid the double margnalization problem. Absent a credible long term contract by ASRC to supply it with sugar at cost, Arbuckle Brothers could only achieve that by retaining its independence in the refining market. ${ }^{63}$

\footnotetext{
${ }^{63}$ Long term contracts in sugar did exist at this time, though in raw, not in refined sugar.
} 


\section{References}

[1] Bolton, Patrick and David Sharfstein. "A Theory of Predation Based on Agency Problems in Financial Contracting." 80 American Economic Review, (1990) 93-106.

[2] Bureau of Labor Statistics. Sugar Prices, from Refiner to Consumer, Government Printing Office, Washington, 1913.

[3] Cabral, Luis M. and Michael H. Riordan, "The Learning Curve, Market Dominance, and Predatory Pricing," Econometrica, (1994) 1115-1140.

[4] Eichner, Alfred S. The Emergence of Oligopoly: Sugar Refining as a Case Study. Johns Hopkins Press, 1969.

[5] Fugate, Francis L. Arbuckles: The Coffee that Won the West. Texas Western Press, University of Texas at El Paso, 1994.

[6] Gelman, J. and S. Salop. "Judo Economics: Capacity Limitation and Coupon Competition." 14 Rand Journal of Economics, (1983) 315-325.

[7] Genesove, David, and Wallace P. Mullin. "Validating the Conjectural Variation Method: The Sugar Industry, 1890-1914." NBER Working Paper 5314, October 1995.

[8] Hanes, Christopher. "The Development of Nominal Wage Rigidity in the late 19th Century." 83 American Economic Review, (1993) 732-756.

[9] Joskow, Paul L. and Alvin Klevorick. "A Framework for Analyzing Predatory Pricing Policy." 89 Yale Law Journal, (1979) 213-270.

[10] Kreps, David and Robert Wilson, "Reputation and Imperfect Information." 27 Journal of Economic Theory, (1982) 253-279.

[11] Lieberman, Marvin B. "Postentry Investment and Market Structure in the Chemical Processing Industries." 18 Rand Journal of Economics, (1987) 533549 .

[12] Milgrom, Paul and John Roberts. "Predation, Reputation, and Entry Deterrence." 27 Journal of Economic Theory, (1982) 280-312. 
[13] Porter, Robert. "A Study of Cartel Stability: the Joint Executive Committee, 1880-1886." 14 Bell Journal of Economics, (1983) 301-314.

[14] Saloner, Garth. "Predation, Mergers, and Incomplete Information." 18 Rand Journal of Economics, (1987) 165-186.

[15] Scott Morton, Fiona. "Entry and Predation: British Shipping Cartels 18791929." NBER Working Paper 5663, July 1996.

[16] Tirole, Jean. The Theory of Industrial Organization. MIT Press, 1988.

[17] United States Industrial Commission. Reports, Volumes 1, 13, 14. Washington, Government Printing Office, 1900.

[18] U.S. Congress, House of Representatives. Special Committee on the Investigation of the American Sugar Refining Company and Others. Hearings 4 Volumes, 1911-1912.

[19] United States Tariff Commission. Refined Sugar: Costs, Prices and Profits. Washington, 1920.

[20] United States Tariff Commission. Effects of the Cuban Reciprocity Treaty of 1902. Government Printing Office, 1929.

[21] Vogt, Paul. The Sugar Refining Industry in the United States. University of Pennsylvania, 1908

[22] Weekly Statistical Sugar Trade Journal. Willett and Gray, 1891-1914.

[23] Weiman, David F. and Richard C. Levin. "Preying for Monopoly? The Case of Southern Bell Telephone Company, 1894-1912." 102 Journal of Political Economy, (1994) 103-126.

[24] Yamey, B. "Predatory Price Cutting: Notes and Comments." 15 Journal of Law and Economics, (1972) 129-142.

[25] Zerbe, Richard O. "The American Sugar Refinery Company 1887-1914: The Story of a Monopoly." 12 Journal of Law and Economics, (1969) 339-375. 


\section{A. Repeated Games}

Price Setting. Demand is assumed identical in each period and competition is by price setting, with recursion to the Nash-Bertrand equilibrium after a deviation. ${ }^{64}$ Equilibrium is described by outputs $\left\{q_{A S R C}, q_{f}\right\}$.

For every $p, q_{f}$ must be such that the fringe has no incentive to deviate:

$$
(p-c) q_{f} \geq(1-\delta)(p-c) K+\delta \pi_{f}^{B}
$$

where $\pi_{f}^{B}$ is the fringe's static Bertrand profits. Thus the minimum $q_{f}$ is

$$
q_{f}^{*} / K=1-\delta\left(1-\frac{\underline{p}-c}{p-c}\right)
$$

ASRC will not undercut if and only

$$
(p-c)\left[D(p)-q_{f}\right] \geq(1-\delta)(p-c) D(p)+\delta \pi^{d}
$$

The maximum $q_{f}$ that ASRC can accept is therefore

$$
q_{f}^{* *}=\delta\left[(p-c) D(p)-\pi^{d}\right] /(p-c)=\delta\left\{D(p)-\frac{\underline{p}-c}{p-c} D(p)\right\}
$$

Collusion at price $p$ is possible, then, if we can find a $q_{f}$ such that $q_{f}^{*} \leq q_{f} \leq q_{f}^{* *}$. Thus we require $q_{f}^{*} \leq q_{f}^{* *}$, that is

$$
\begin{gathered}
\{(1-\delta)(p-c)+\delta(\underline{p}-c)\} K \leq \delta\{(p-c) D(p)-(\underline{p}-c) D(\underline{p})) \\
\pi_{f}^{B}+\pi^{d}=(\underline{p}-c)(K+D(\underline{p})) \leq(p-c)\left[D(p)-\frac{(1-\delta)}{\delta} K\right]
\end{gathered}
$$

The term on the far left is expected industry profits in the static Bertrand game. The term on the right is maximized by the dominant firm price corresponding to fringe capacity $\frac{(1-\delta)}{\delta} K$. When $\delta=1,($ A.3) holds for the monopoly price and some range of prices beneath it, since monopoly profits exceed the Bertrand industry profits. The condition does not hold for $\delta=1 / 2$, at which point the hypothetical fringe capacity equals $K$ itself, so that the right hand side's maximal value is $\pi^{d}$. Thus collusion is only sustainable for $\delta \geq \delta^{*}>1 / 2$.

Given the speed of price recognition and reaction in this industry, it is interesting to consider the case of $\delta=1$. Then, when, $q_{f}=q_{f}^{* *}$, ASRC earns its

\footnotetext{
${ }^{64}$ We are examining subgame perfect equilibria throughout.
} 
dominant firm profits, whereas for the same $\delta$ and $q_{f}=q_{f}^{*}$, the fringe earns its static Bertrand profits.

In repeated quantity setting, with $K$ an effective constraint, the deviation profits in the future are those of the dominant firm model. The fringe's optimal deviation is to produce $K$, so the condition for no profitable deviation is

$$
\begin{gathered}
(p-c) q_{f} \geq(1-\delta)(p-c) K+\delta\left(p^{d}-c\right) K \\
q_{f} / K=1-\delta+\delta \frac{p^{d}-c}{p-c}
\end{gathered}
$$

ASRC's optimal deviation is to dominant firm output or pricing with fringe capacity $q_{f}$. Thus its incentive compatibility constraint is

$$
(p-c)\left(D(p)-q_{f}\right) \geq(1-\delta) \max \left\{(p-c)\left(D(p)-q_{f}\right)\right\}+\delta \pi^{d}
$$

If we consider the case $\delta=1$, and $p=p^{M}$, we obtain from (A.4) and (A.5)

$$
\begin{gathered}
q_{f} / K \geq \frac{p^{d}-c}{p^{M}-c} \\
\left(p^{M}-c\right) q_{f} \leq \pi^{M}-\pi^{d}
\end{gathered}
$$

Again, the maximum fringe production is that which gives ASRC its dominant firm profits, while the minimum fringe production is that which gives the fringe not its repeated Bertrand profits, but its profits in the dominant firm equilibrium. 


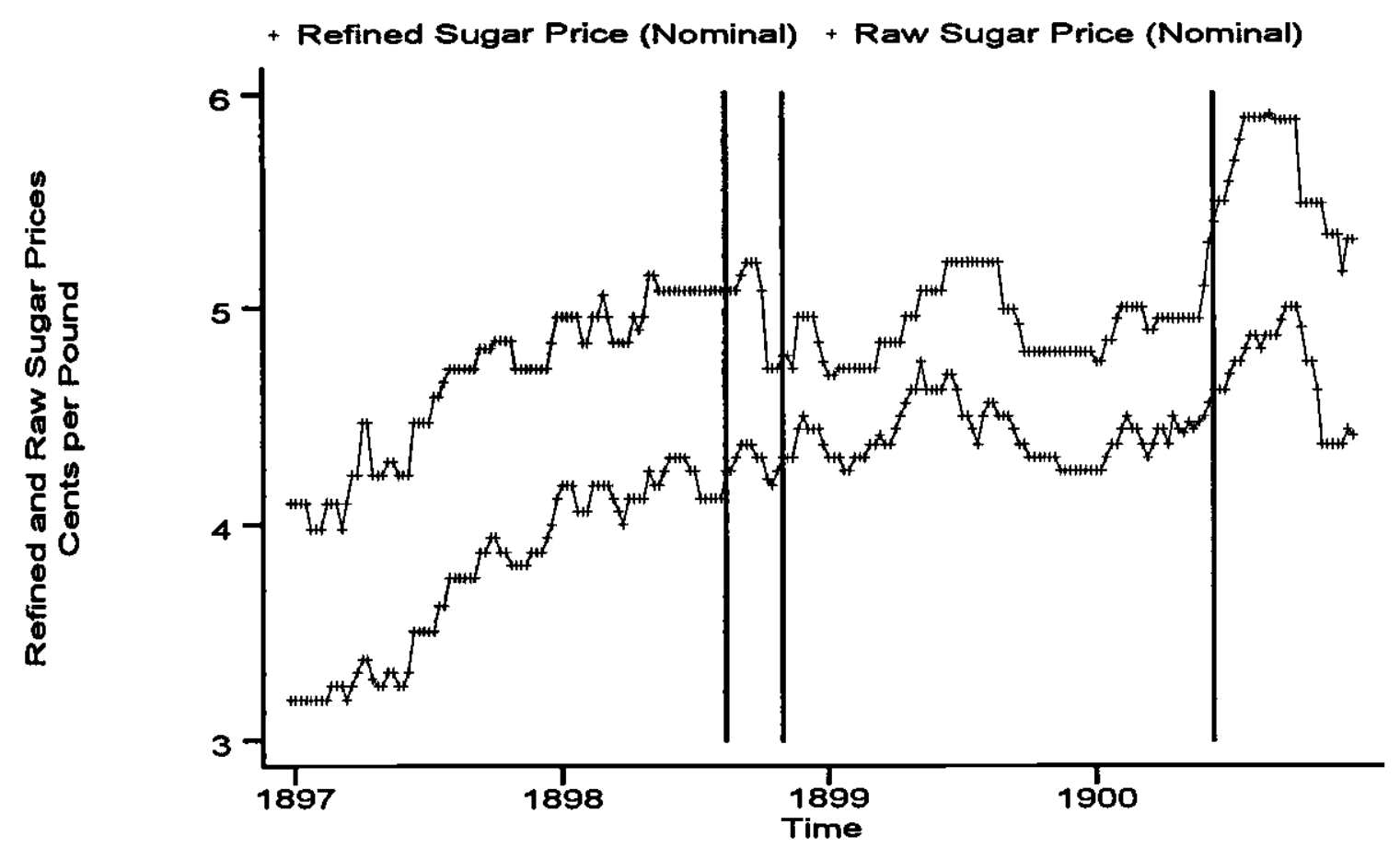

Figure 1: Effect of Arbuckle, Doscher 


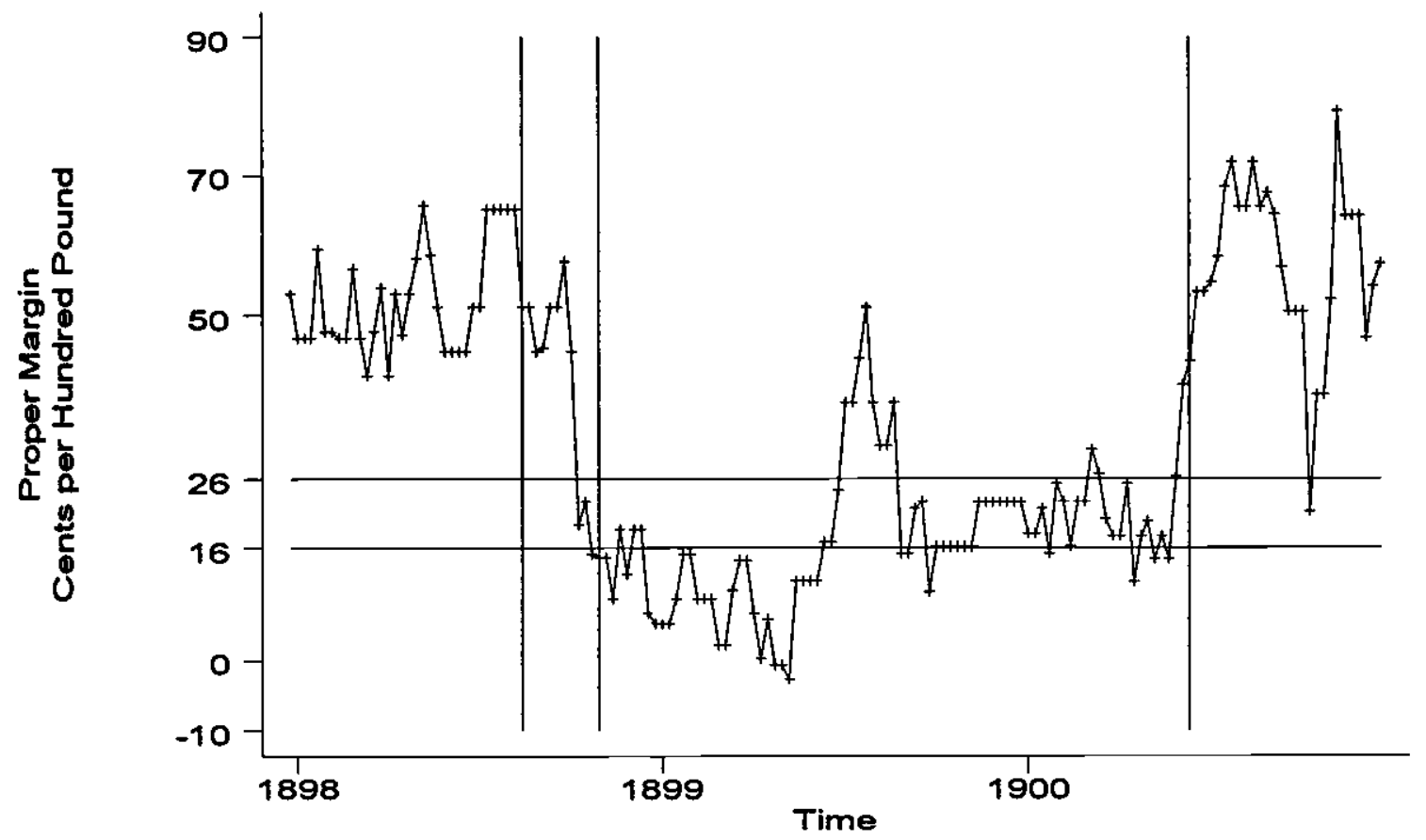

Figure 2: Arbuckle War 


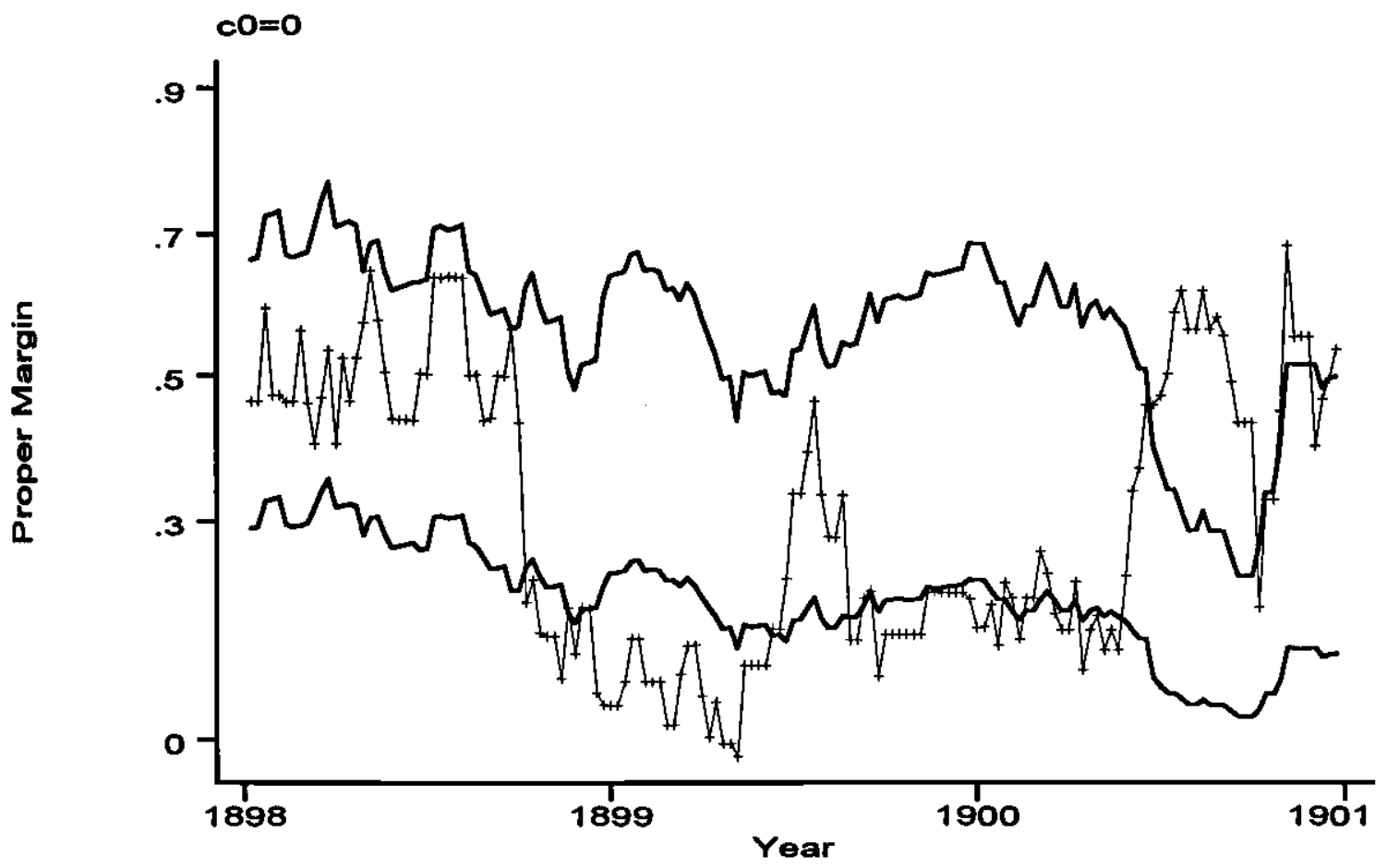

Figure 3a: Proper Margins, Actual, Dominant Firm \& Bertrand 


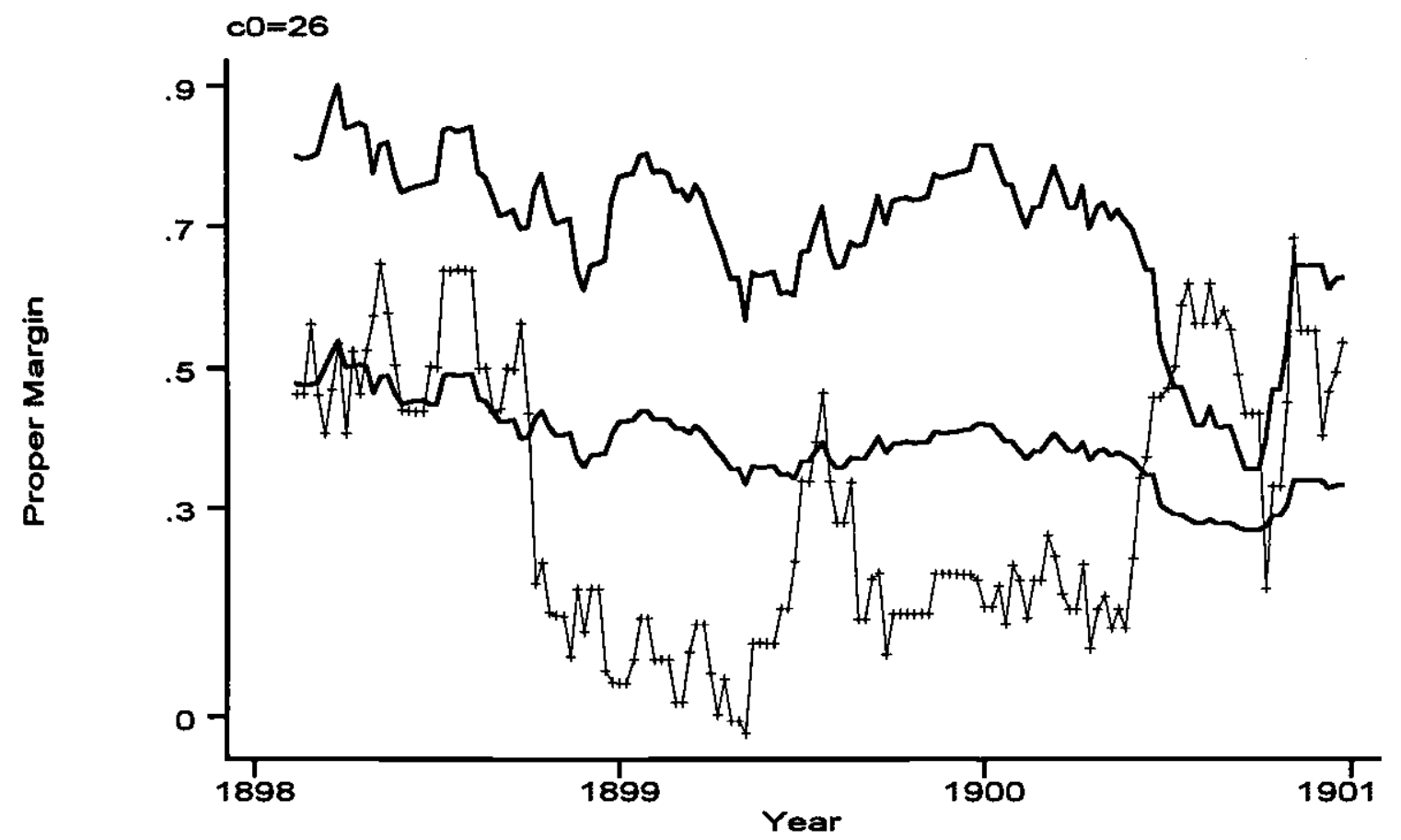

Figure 3b: Proper Margins, Actual, Dominant Firm \& Bertrand 


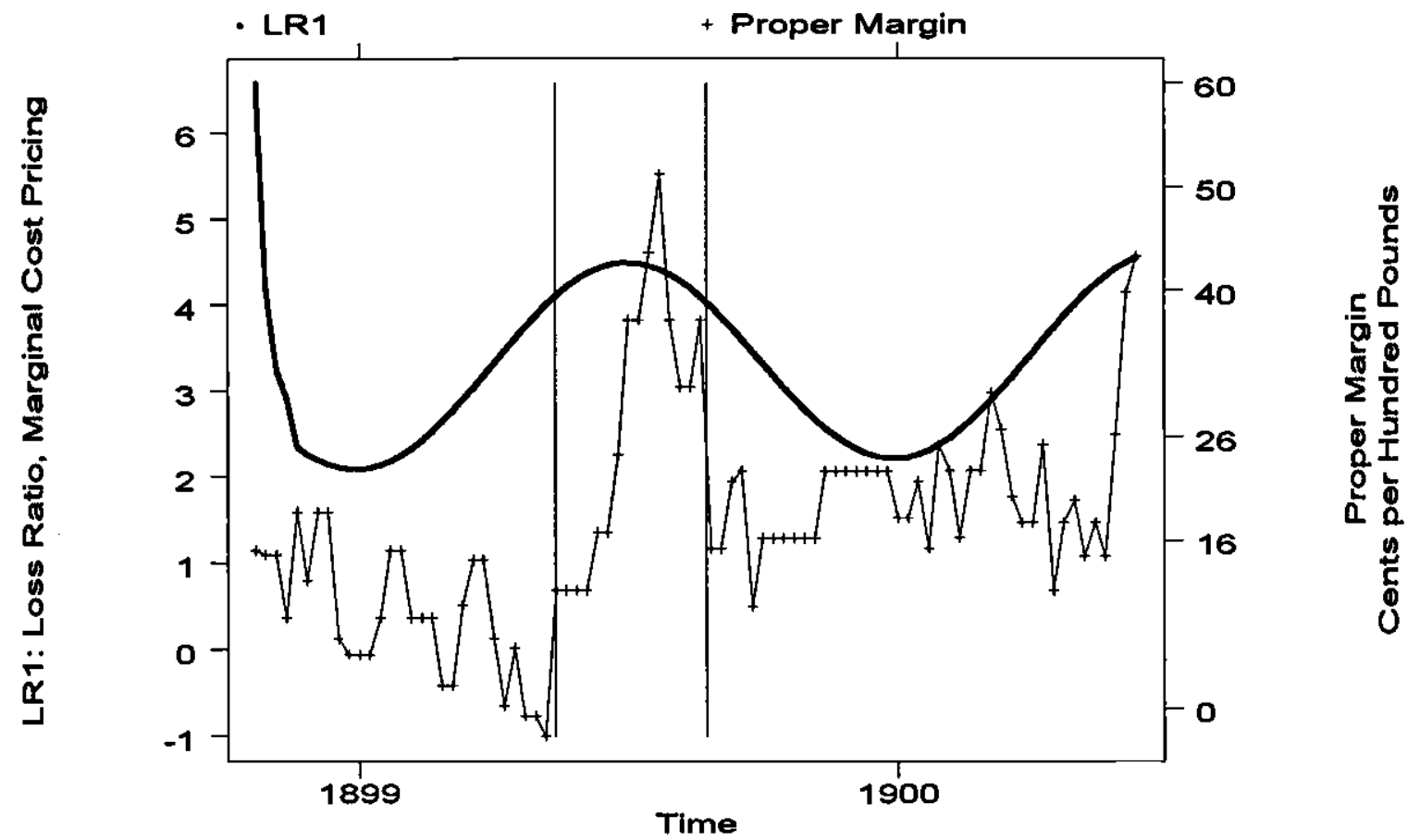

Figure 4: Cost of Zero Profit Predation, Arbuckle War 


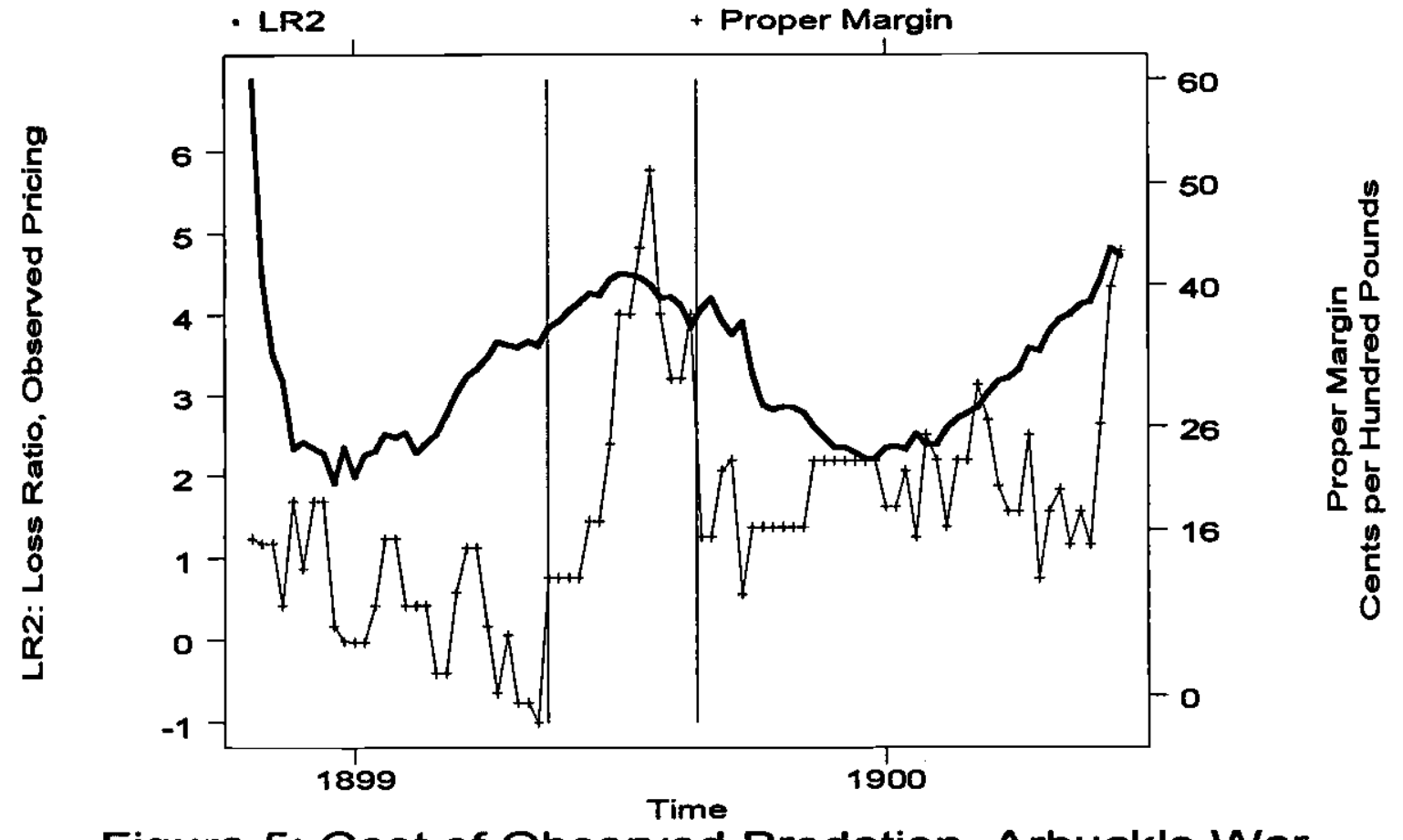

Figure 5: Cost of Observed Predation, Arbuckle War 


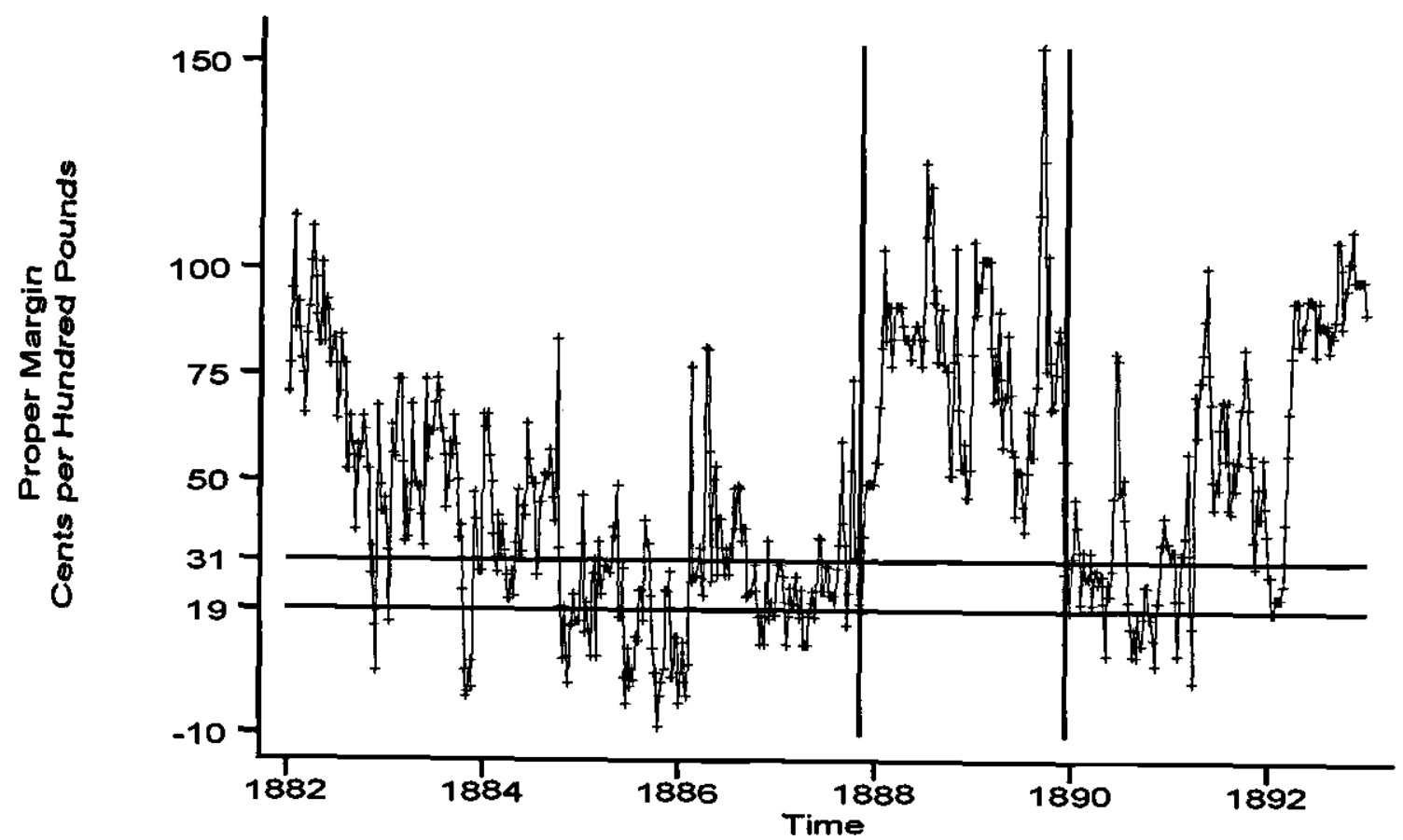

Figure 6: Proper Margin, 1882-1892 


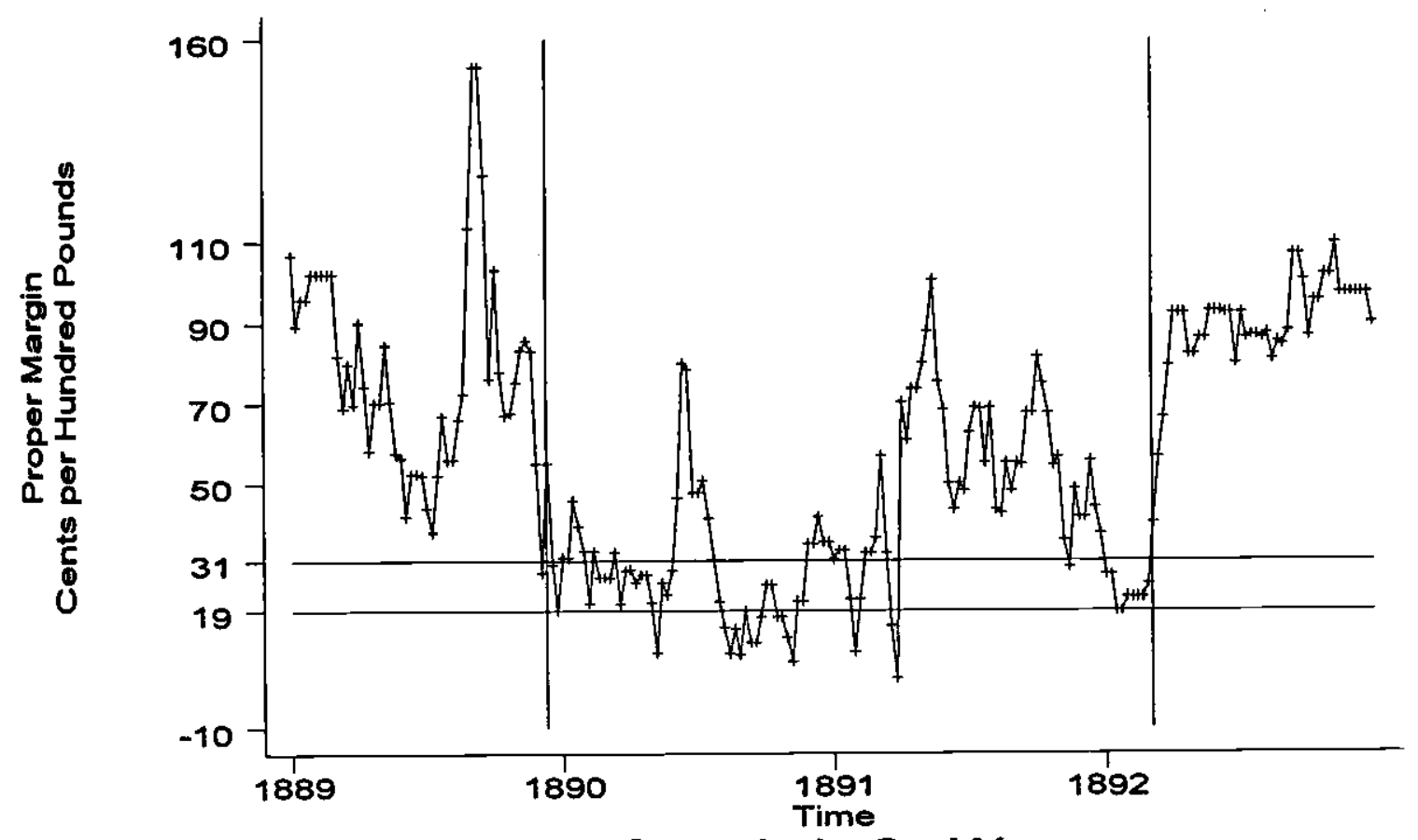

Figure 7: Spreckels Sr. War 